\title{
Consequences of land-use change and the wildfire disaster of 2017 for the central Chilean biodiversity hotspot
}

\author{
Andreas Ch. Braun ${ }^{1}$ (D) $\cdot$ Fabian Faßnacht ${ }^{2} \cdot$ Diego Valencia $^{3} \cdot$ Maximiliano Sepulveda $^{3}$
}

Received: 8 July 2020 / Accepted: 6 February 2021 / Published online: 25 March 2021

(C) The Author(s) 2021

\begin{abstract}
Central Chile is an important biodiversity hotspot in Latin America. Biodiversity hotspots are characterised by a high number of endemic species cooccurring with a high level of anthropogenic pressure. In central Chile, the pressure is caused by land-use change, in which near-natural primary and secondary forests are replaced and fragmented by commercial pine and eucalyptus plantations. Large forest fires are another factor that can potentially endanger biodiversity. Usually, environmental hazards, such as wildfires, are part of the regular environmental dynamic and not considered a threat to biodiversity. Nonetheless, this situation may change if land-use change and altered wildfire regimes coerce. Landuse change pressure may destroy landscape integrity in terms of habitat loss and fragmentation, while wildfires may destroy the last remnants of native forests. This study aims to understand the joint effects of land-use change and a catastrophic wildfire on habitat loss and habitat fragmentation of local plant species richness hotspots in central Chile. To achieve this, we apply a combination of ecological fieldwork, remote sensing, and geoprocessing to estimate the spread and spatial patterns of biodiverse habitats under current and past land-use conditions and how these habitats were altered by land-use change and by a single large wildfire event. We show that land-use change has exceeded the wildfire's impacts on diverse habitats. Despite the fact that the impact of the wildfire was comparably small here, wildfire may coerce with land-use change regarding pressure on biodiversity hotspots. Our findings can be used to develop restoration concepts, targeting on an increase of habitat diversity within currently fire-cleared areas and evaluate their benefits for plant species richness conservation.
\end{abstract}

Keywords Wildfire $\cdot$ Biodiversity hotspot $\cdot$ Central Chile $\cdot$ Plantation forestry $\cdot$ Landscape metrics

Communicated by Wolfgang Cramer

Andreas Ch. Braun

andreas.ch.braun@kit.edu

Fabian Faßnacht

fabian.fassnacht@kit.edu

Diego Valencia

diego.valencia@conaf.cl

Maximiliano Sepulveda

maximiliano.sepulveda@conaf.cl

1 Insitute of Regional Science (IfR), Karlsruhe Institute of Technology (KIT), Kaiserstraße 12, 76131 Karlsruhe, Germany

2 Institute of Geography and Geoecology (IFGG), Karlsruhe Institute of Technology (KIT), Kaiserstraße 12, 76131 Karlsruhe, Germany

3 Corporación Nacional Forestal (CONAF), Paseo Bulnes 285, Santiago, Chile

\section{Introduction}

Biodiversity is endangered by mankind in many regions worldwide (Butchart et al. 2010; McKee et al. 2004; Cardinale et al. 2018). Major threats to biodiversity arise from anthropogenically induced spatial processes (such as urbanization, infrastructure development, or land-use change), which result in habitat fragmentation and destruction (Fardila et al. 2017; Fahrig 2003; Krauss et al. 2010). Prioritization concepts for biodiversity conservation are required, and several approaches have been proposed in literature (Brooks et al. 2006; Asaad et al. 2017; Naidoo et al. 2008).

Amongst the most recognized concepts are biodiversity hotspots according to Myers et al. (2000). By definition, biodiversity hotspot is characterised by (1) a high number of species, especially endemic species, and (2) a severe threat to biodiversity due to anthropogenic processes, particularly 
human population pressure (Cincotta et al. 2000) which often translates in land-use changes, one of the principal drivers of biodiversity loss (Reidsma et al. 2006; Sala et al. 2000).

Central Chile is an example of such a biodiversity hotspot. The region is characterised by a large number of native and endemic species which are endangered by silvicultural expansion (Alaniz et al. 2016; Ormazabal 1993; Smith-Ramírez 2004). Commercial monospecific plantations of nonnative Pinus spp. and Eucalyptus spp. have in many regions replaced a large share of the near natural forests which harbour high native plant species richness (Andersson et al. 2016; Salas et al. 2016; Clapp 1995a, b, 2001). Hence, plantation establishment has caused large-scale habitat destruction and fragmentation (Echeverria et al. 2006, 2008; Bustamante et al. 2003). Habitat loss and fragmentation have been shown to impose serious threats to biodiversity (Fahrig 2003; Fardila et al. 2017). For Chile, impacts on biodiversity have been assessed in situ (Braun et al. 2017; Heinrichs and Pauchard 2015) and with spatially explicit plant species richness models (Braun and Koch 2016; Altamirano et al. 2010). The existing concept for biodiversity conservation in Chile has received criticism (Jorquera-Jaramillo et al. 2012; Petit et al. 2018; Smith-Ramírez et al. 2015; Luque 2017). Particularly, the effectiveness of the Chilean System of National Parks and Reserves (Sistema Nacional de Áreas Silvestres Protegidas del Estado, SNASPE; for a list of abbreviations, see Table 1) has been questioned, since a large part of its protected areas are located in southern parts of the country. Within our study site, protected areas are predominantly found in the Andes, where land-use pressure is low anyway (CifuentesCroquevielle et al. 2020; Pliscoff and Fuentes-Castillo 2011; Squeo et al. 2012; Jorquera-Jaramillo et al. 2012; Petit et al. 2018).

Hence, protecting the remaining patches of near natural secondary forests is of crucial importance to maintain Chile's plant species richness at a level qualifying it as a biodiversity hotspot (Pimm et al. 2014). Today, these small remnant natural forest patches of a couple of hectares to square kilometres occur mainly immersed in a matrix of commercial plantations (Bustamante and Castor 1998). This situation leads to further threats to these areas as, along the plantation management cycle, these native forest patches are frequently (1) replaced with plantations, (2) degraded due to heavy machinery used in directly bordering areas, or (3) degraded by sedimentation from adjacent slopes during the winter rains and after harvesting. Furthermore, they are (4) affected by biodiversity loss due to habitat isolation (Clapp 1995a, b, 2001; Rüger et al. 2007).

The effect of forest fires on biodiversity remains to be evaluated. Central Chile is characterized by a Mediterranean climate and a transition zone between sclerophyllous and deciduous vegetation. While natural wildfires are not typical for the region, human-induced wildfires have become alarmingly more frequent during the last decades (Armesto et al. 2009; Contreras et al. 2011). McWethy et al. (2018) have identified land-use change as an important driver of wildfire activity in Chile. Commercial tree plantations are significantly more prone to incinerate (e.g., due to dry fine fuel loading below

Table 1 List of abbreviations used in this article. General abbreviations, names of dataset, and analysis outcomes (excluding landscape metrics, which are described in Table $\mathrm{X}$ )

\begin{tabular}{|c|c|c|}
\hline Abbreviation & Meaning & Comments \\
\hline SNASPE & Sistema Nacional de Áreas Silvestres Protegidas del Estado & National System of State Wildlife Protected Areas \\
\hline LUM & Land-use maps & Conditions: $1975,1980,1985, \ldots, 2015$ \\
\hline LTS & Landsat time series & \\
\hline BES & Plant species richness estimate & Conditions: 1975, 2015 (prefire) and postfire \\
\hline PAM & Plantation age map & \\
\hline PTM & Plantation type map & \\
\hline DEM & Digital elevation model & \\
\hline BDA & Biodiversity analysis & \\
\hline BDR & Biodiversity releves & \\
\hline SFM & Severe fire mask & \\
\hline 1_LOHO & Primary local biodiversity hotspot & \\
\hline 2_LOHO & Secondary local biodiversity hotspot & \\
\hline Percent_of_75 & $\begin{array}{l}\text { Percentage of remaining numbers/areas of biodiversity hotspots } \\
\text { in comparison to } 1975\end{array}$ & \\
\hline $\begin{array}{l}\text { Percent_of_ } \\
\text { Previous }\end{array}$ & $\begin{array}{l}\text { Percentage of biodiversity hotspots remaining from the previous } \\
\text { step }\end{array}$ & \\
\hline chg & Change of landscape metrics & $\begin{array}{l}\text { Conditions: loss }(65-95 \%) \text {, gain }(105-135 \%) \text {, strong loss }(<65 \%) \text {, } \\
\text { strong gain }(>135 \%) \text {, no change (noch) }\end{array}$ \\
\hline
\end{tabular}


the Pinus spp. canopy or due to strongly combustible Eucalyptus spp. foliage) (Peña and Valenzuela 2008; Garfias et al. 2012; Bowman et al. 2016) and to cascade into crown fires via combustible shrubs (e.g., Teline monspessulana (L.) $\mathrm{K} . \mathrm{KoCH})$. The presence of tree plantations helps wildfires to spread quickly over the landscape due to the voluminous stands and the continuous spatial structure of the plantations and hence also increases the probability of adjacent natural ecosystems to incinerate (Gonzalez et al. 2011; Castillo et al. 2012; Pauchard et al. 2008). Further, land-use change reduces near natural ecosystems to scattered remnants, which potentially may be less able to recover from a wildfire than large patches of forests (Abella and Fornwalt 2015; Donato et al. 2006; Crane et al. 2017; Bowd et al. 2018). Studies from Chile suggest that negative effects on biodiversity due to patch isolation may be limited due to postfire regeneration ability, but more research is needed with respect to high intensity/large scale wildfires (Montenegro et al. 2003; Gómez-González et al. 2011).

The fire sensitivity of the central Chilean vegetation must, however, be discussed in a differentiated fashion. The Chilean matorral is considered to be fire-adapted (e.g., Gonzalez et al. 2010; Gómez-González et al. 2011; Montenegro et al. 2004). Nonetheless, we cannot generally assume the vegetation in our study site to be resilient to wildfires of higher frequencies or intensities. Gómez-González et al. (2017) have shown negative seed responses to fire cues in germination experiments. They conclude that the Chilean matorral is not fire-adapted to the extent that Mediterranean ecosystems typically are. Further, Central Chile comprises not only the sclerophyllous matorral but also the Nothofagus stands, Myrtacea forests along river banks, the forest stands of the preandean range, and the Araucaria forests. Nothofagus stands are assumed to tolerate wildfires (Litton and Santelices 2002; White et al. 2020). However, for some of these stands, the adaptation to fire is unclear. Urrutia-Estrada et al. (2018) and FuentesRamírez et al. (2020) have found impacts on plant species biodiversity after moderate and severe fires. However, their studies have been performed based on data from one year after the fire and cannot represent long-term trends. Assal et al. (2018) have demonstrated canopy mortality by wildfires in Araucaria-Nothofagus forests. However, their study does not cover plant mortality. Finally, González et al. (2016) have shown that wildfires transform Chilean forests from primary to secondary forest, which may host a reduced biodiversity.

The mentioned landscape composition with native forests frequently being surrounded by pine plantation is a further factor that increases the potential threat of wildfires to the region's biodiversity. Many burnt smaller native forest patches are likely to be affected by large-scale invasions of seedlings from the fire-adapted plantation species Pinus radiata and Eucalyptus globulus which can easily outcompete the native tree species during the establishment phase and are hence likely to grow permanently in areas formerly stocked with native forests (Litton and Santelices 2002).

Some of the abovementioned assumptions have manifested in 2017 when January and February huge wildfires burned in many parts of Chile, as a consequence of a long-term drought combined with ignitions caused by the transit of people or vehicles and arson (Martinez-Harms et al. 2017). According to CONAF data, the fires of 2016/2017 covered $39 \%$ of the total burnt area between 1985 and 2020. Fires affected commercial plantations and also the near natural forest patches between them (Castillo et al. 2017; Molina et al. 2017). The ecological consequences of these wildfires have not yet been investigated thoroughly.

In the light of this situation, we address the following research objectives: (1) we first outline the impact of land-use pressure on habitat loss and connectivity of local plant species richness hotspots over the last 40 years (1975-2015), and (2) we then assess the additional impact caused by the wildfires in 2017.

Note that our study relates the impact of land-use change to the extensive forest fires of 2017. The following reasons support the approach. Firstly, such extensive forest fires are expected to become more frequent due to a combination of landuse and climate change and therefore need to be researched (McWethy et al. 2018). Second, some ecosystems that belong to Chilean vegetation may be unadapted to forest fires (González et al. 2016). Third, the results are important for the scientific discourse about the influences of such to Chilean ecosystems. An analysis of the total impact of wildfires since 1975 would be interesting but is technically intricate (due to difficulties in reconstructing all wildfires spatially explicitly). Therefore, such an analysis is neither the focus nor within the scope of this article.

\section{Study site}

The study site comprises the VII. Región del Maule and the VIII. Región del BioBío, ranging from 72 to $73^{\circ} \mathrm{E}$ and 36 to $38^{\circ} \mathrm{S}$, cf. Fig. 1. The regions are characterized by a Csbclimate (Kottek et al. 2006; Peel et al. 2007), with an average annual temperature of $13.1^{\circ} \mathrm{C}$ and a precipitation sum of 1294 $\mathrm{mm}$. Towards the north, the Csb-climate gets warmer and dryer; the same accounts for the interior (Luebert and Pliscoff 2006). The region's geology is structurally characterized by subduction tectonics causing frequent strong earthquakes. Lithologically, Quaternary, Tertiary, and also Precambrian-Paleozoic sediments characterize the coast, followed by Paleozoic-Mesozoic intrusives in the coastal range, Quartenary sediments in the central valley, and Quarternary and Cretaceous-Tertiary volcanics in the Andean range. The regions are drained by large antecedent 
Fig. 1 Topographical overview of the study site. Administrative boundaries, urbanization, hydrology, elevation, protected areas (SNASPE) and wildfires of 2017

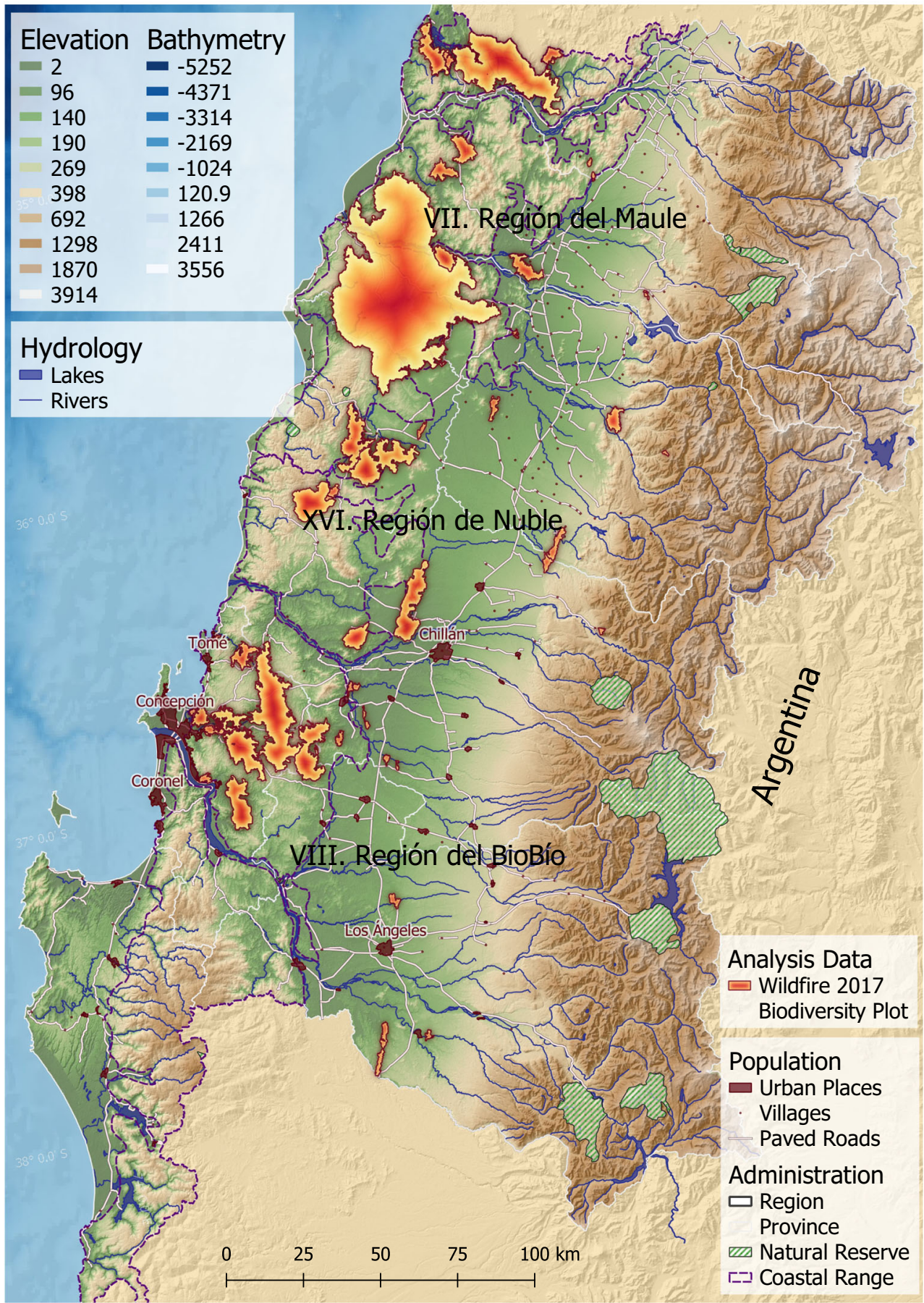

drainage streams (BioBió $353 \mathrm{~m}^{3} \mathrm{~s}^{-1}$, Itata, $186 \mathrm{~m}^{3} \mathrm{~s}^{-1}$, Maule $467 \mathrm{~m}^{3} \mathrm{~s}^{-1}$ ) (Moreno and Gibbons 2007). These settings create a morphology characterized by a midelevation coastal range of $400 \mathrm{~m}$ a.s.l. on average, a central valley with an elevation of around $145 \mathrm{~m}$ a.s.l., and the Andean range with a maximum elevation of $2418 \mathrm{~m}$ a.s.l. in the study site (from west to east). Note that in the south of the VIII. region, the Nahuelbuta range elevates up to over $1300 \mathrm{~m}$ a.s.l. The natural vegetation of the coastal range are (from north to south) sclerophyllous forests (dominated by Peumus boldus (Molina), Cryptocarya alba (Molina) Looser), deciduous forests (dominated by Nothofagus spp.), and conifer forests (dominated by Araucaria araucana (MolinA) K. KocH), as well as pseudosavannas of Acacia caven (MoLINA) in the central valley (Ovalle et al. 1990; Fuentes et al. 1989). The region is considered a biodiversity hotspot according to Myers et al. (2000) since it hosts 3429 plant species, with 1605 being endemics ( $\sim 0.5 \%$ of global endemics) and 335 vertebrate 
Fig. 2 Land-use information for study site. Green areas represent near natural forests in 2015. Purple areas represent sites where forests have been cleared in favour of plantations between 1975 and 2015. Biodiversity plots assessed by Braun (2013) as small crosses

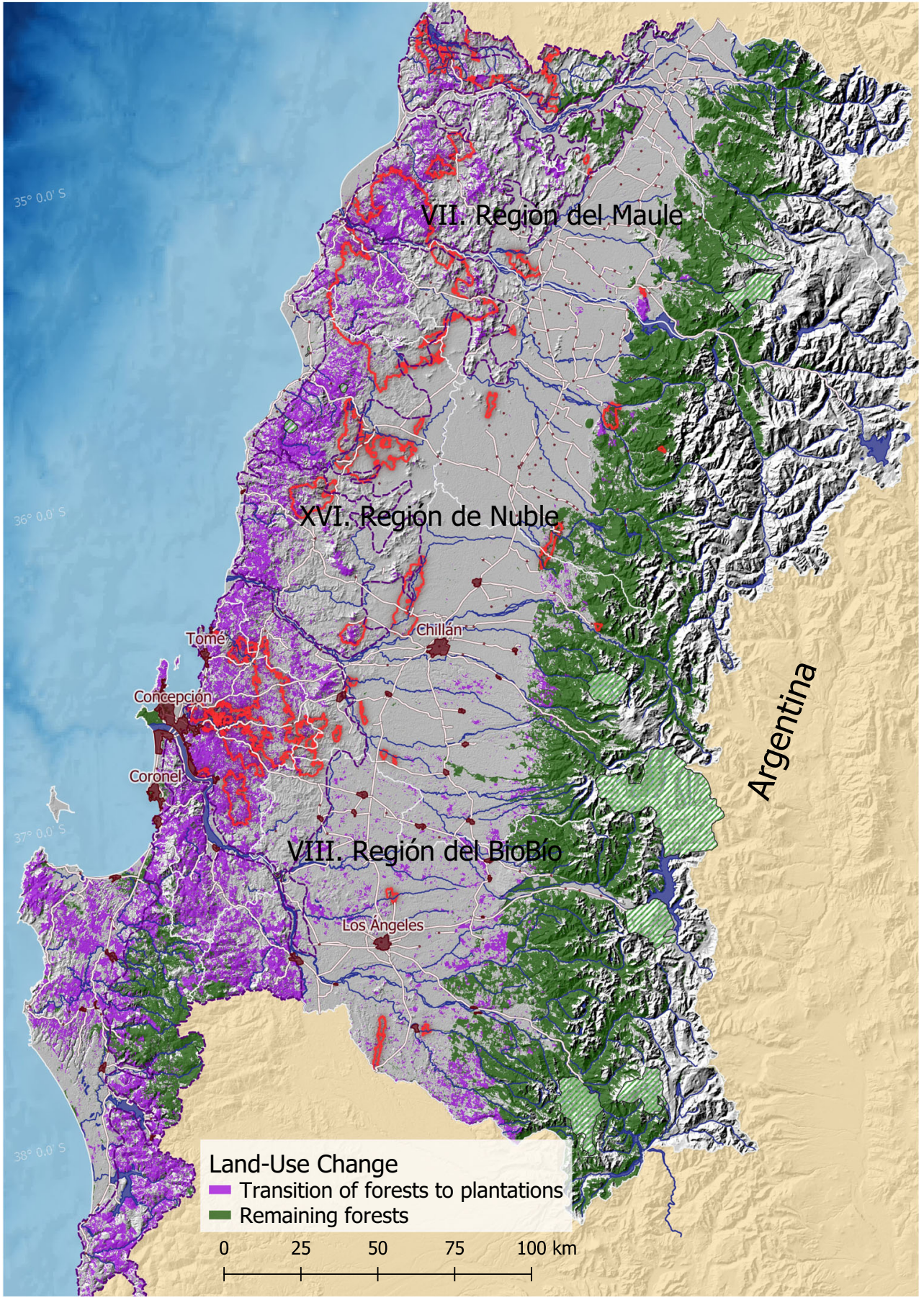

species with 61 being endemics ( $\sim .2 \%$ of global endemics). The original extent of $300,000 \mathrm{~km}^{2}$ of natural vegetation has been reduced to $90,000 \mathrm{~km}^{2}$ (30\% of original extent), and only $9167 \mathrm{~km}^{2}$ is protected ( 10.2\% of the hotspot) (Myers et al. 2000; Zuloaga et al. 2008).

Chile experienced a large scale establishment of monospecific plantations of Pinus spp. and Eucalyptus spp. over the last decades. Modern silvicultural practices began in the region by the end of the eighteenth century. First afforestations were conducted to stabilize soil on abandoned crop and stock farming sites, as well as to commercially produce wood (Clapp 1995a; cf. Banfield et al. 2018 for a critical view). During the economic transition from a socialist towards a capitalist economic system, realized by the Pinochet dictatorship, the law DL 701 created strong economic incentives for the expansion of commercial plantations. The costs for establishing plantations on suitable sites were subsidized by $75 \%$; refraining to do so would be sanctioned fiscally (Langenfeld 2017; Bitterlich 2001; Salas 1998). Plantation stands are composed of even-aged cohorts, harvested with clearcutting and 
subsequent herbicide application and fire clearance (Langenfeld 2017; Bitterlich 2001; Salas 1998). These management strategies often maintain no native species below the canopy (Braun et al. 2017; Braun and Vogt 2014). Plantations expanded from 1974 onwards with growth rates of 6 to $8 \%$ annually in the study sites (Miranda et al. 2017, cf. Fig. 2). Plantations were predominantly established by replacing near natural forests (Braun 2013). Near natural forests, today, are limited to small patches of (privately owned) remnants, frequently exploited for firewood extraction, waste disposal, and wood pastures. These land-uses degrade the remnants considerably (Rojas et al. 2011; Ramírez et al. 1988).

Regarding the wildfire regime, Chile has a long history of manmade burning for land clearance and management (Armesto et al. 2009; Contreras et al. 2011). Most fires (44\%) incinerate due to vehicular transport (e.g., cigarettes thrown out of the driving car), tourism activities (camp fires) (27\%), and intentional arson (18\%). Occasionally, fires are due to volcanic origin, but natural fires are remarkably rare. Fire frequency is approximately one fire per 1752 ha per year, and fires occur mostly in grasslands, followed by shrublands and plantations, and rarely incinerate in native forests. Fire size is, on average, $6000 \mathrm{~m}^{2} ; 92.6 \%$ are below 5 ha and only $0.6 \%$ over 200 ha. Fire intensity is typically of low and medium calorific power. Most fires (90\%) occur in summer, which is due to prevailing heat, drought, and accumulation of dead biomass and fine fuel loading during this season (Contreras et al. 2011). McWethy et al. (2018) show high seasonal variability of fire activity with no clear trend for the time period between 2001 and 2017. They state that land-use patterns, mostly plantation forestry and agriculture promote fire activity.

The wildfires of December 2016 to February 2017 affected at least $6000 \mathrm{~km}^{2}$ of tree covered surface in seven regions of the country. With over 280,000 ha in the VII. and over 99,000 ha in the VIII. region, our study site does not only represent the centre of the biodiversity hotspot but also the area most strongly affected by the wildfire disaster in the fire season 2016-2017 (CONAF 2017). Castillo et al. (2017) and Gonzalez et al. (2018) provide some first results on the ecological effects of the 2017 wildfires. Gómez-González et al. (2017) have provided insights on the recovery of vegetation after the fire. This study aims to assess the short-term damage of the wildfire disaster to plant species richness patterns and to provide information to develop a conservation approach aiming at preserving regional plant species richness (Lindenmayer et al. 2006; Donato et al. 2006; Willis and Birks 2006).

\section{Materials and methods}

This study builds on extensive previous work by the authors. Previous work focusses firstly on land-use change analyses in the study site, based on remote sensing data. Secondly, plant species richness conditions in different land-use systems were evaluated on the basis of vegetation relevés and plant species richness indicator analyses. Thirdly, the land-use change analyses were coupled with plant species richness analyses to provide a map with spatially explicit plant species richness estimates for the entire study site. This plant species richness map represents the centre of this study (although in an updated version). The preliminary work is published in several studies (Braun and Koch 2016; Braun et al. 2017). In the "Materials" section and Table 1 (Appendix), we provide a brief overview how these datasets were created, but we refer to the published studies for more details. The entire framework (of the previous and the current) study is presented in Fig. 1 in the Appendix.

\section{Materials}

\section{Land-use maps (LUM)}

Based on a Landsat time series (LTS), we analysed land-use change drivers for the entire study site, in 5-year intervals $(1975,1980, \ldots, 2010)$ (Braun 2013). For each 5-year time interval, a land-use map (LUM-1975 to LUM-2010) with 7 classes is available ( $1=$ near natural forest, $2=$ plantation, $3=$ agriculture, $4=$ scrubland, $5=$ clearcut, $6=$ urban area, $7=$ water). The land-use information in these maps is combined with biodiversity data that represent biodiversity conditions within the land-use types. By doing so, spatially continuous biodiversity estimates (BES) based on plant species richness are produced. BES helped to identify local plant species richness hotspots, and to provide an empirical basis to assess the landuse impact on plant species richness.

\section{Plantation age map (PAM)}

Plant species richness within plantations depends on plantation age (Braun 2013). In order to produce a spatially explicit estimate of biodiversity (BES) or plant species richness, plantation age is hence a relevant variable. We used the 5-year interval land-use data (LUM-1975 to LUM2010) to derive plantation age. Age is calculated based on the continuity of a pixel belonging to the land-use class $2=$ plantation in the time span before 2010. For each pixel categorised as a plantation in 2010 (i.e., in LUM-2010), the point in time is identified when this pixel was first classified as a plantation. For instance, a pixel classified as plantation in LUM-2010, LUM-2005, LUM-2000, and LUM-1995 is considered to be a plantation of an estimated age of 2010-1995=15 years (Braun 2013).

\section{Plantation type map (PTM)}

As Braun (2013) and Braun et al. (2017) show, biodiversity within plantations depends also on plantation type (i.e., 
P. radiata or E. globulus). Hence, we also derived a plantation type map (PTM) for all pixels identified as plantation in 2010 (i.e., in LUM-2010). For these pixels, a supervised classification algorithm is used, which assigns each plantation pixel either to category 1 ( $P$. radiata) or category 2 (E. globulus). The resulting maps had an accuracy of over $95 \%$ (Braun 2013).

\section{Digital elevation model (DEM)}

Plant species richness in near natural forest ecosystems also depends on the type of forests, which in turn depends on altitude above sea level (Braun 2013). For instance, mountainous Araucaria araucana forests show a different species composition and diversity than riparian Luma apiculata forests in the lower parts of the coastal range do. To represent this altitudinal influence on the biodiversity estimates (BES), we also considered a digital elevation model (DEM). The land-use maps (LUM) may only distinguish between forests and other classes but not between forest types. Knowing that A. araucana forests typically appear only above $800 \mathrm{~m}$ a.s.l., the DEM is combined with the LUM to map their presence. Note that the authors did not produce the DEM but employ the widely used ASTER-DEM (Tachikawa et al. 2011). The ASTER-DEM is given as a GeoTiff dataset with $30 \times 30 \mathrm{~m}$ pixel size.

\section{Biodiversity analysis (BDA)}

The Convention on Biological Diversity (CBD) defines biodiversity broadly as "the variability amongst living organisms from all sources, including 'inter alia', terrestrial, marine, and other aquatic ecosystems and the ecological complexes of which they are part: this includes diversity within species, between species and of ecosystems". A large set of methods and indicators have been developed to assess it (Magurran and McGill 2011). Amongst others, plant species richness at the plot scale (alpha-scale of biodiversity) has been suggested as a reliable proxy for total biodiversity (Crutsinger et al. 2006; Zhang et al. 2016). In order to compare plant species richness conditions between near natural forests, plantations and shrublands, 175 plant species richness relevés (BDR) were sampled according to Braun-Blanquet (1964). Relative abundances were derived (cf. Pellissier et al. 2004), and biodiversity indices were calculated. We computed species richness and Simpson index according to the framework provided by Tuomisto (2010a, b, c). Biodiversity conditions were statistically evaluated on the basis of boxplots, and differences between biodiversity conditions in different land-use systems were assessed by one-way ANOVA. Results are published in Braun et al. (2017).

\section{Biodiversity estimate (BES)}

In order to produce spatially explicit estimates of plant species richness throughout the study region, we combined the biodiversity analysis described above with the derived landuse products ("Land-use maps (LUM)" to "Digital elevation model (DEM)" sections). Several approaches exist for estimating biodiversity from remote sensing and other geospatial information (Kerr and Ostrovsky 2003; Turner et al. 2003; Nagendra 2001; Gould 2000). In Braun and Koch (2016), we developed an approach to spatially interpolate our knowledge on biodiversity conditions (represented by local field plots) to the entire study site (represented by land-use data, plantation age and type data, and digital elevation). The approach formulates hypotheses on the quantity of biodiversity (derived from the biodiversity analysis described in the "Biodiversity analysis (BDA)" section) based on certain topographical and land-use situations and the spatial context. It then uses the geospatial layers (LUM, PAM, PTM, and DEM) to identify comparable situations for the entire study site. Finally, it assigns plant species richness estimates to all areas (pixels), according to their particular land-use situation. An example for one such hypothesis outlines the approach:

Step 1: Hypothesis from BDA: Mountainous A. araucana show an average species diversity of 11 species

Step 2: Identify forest areas in LUM-2015 $\rightarrow$ forest polygon (Fpoly)

Step 3: Identify areas above 800 m.a.s.l. $\rightarrow$ mountain polygon (Mpoly)

Step 4: Intersect forest polygon and mountain polygon $\rightarrow$ mountainous forest polygon (MFpoly)

Step 5: Assign a plant species richness estimate value of 11 to the areas within MFpoly

Step 6: Proceed to next hypothesis

In total, seven such hypotheses translated into geospatial rules are applied consecutively. PAM is used to model the influence of plantation age on plant species richness within plantations; PTM models the influence of the plantation type. Effects of adjacency between forests and plantations are also represented. The biodiversity analysis (BDA) has shown that forest biodiversity tends to decrease by $10 \%$ where plantations are within a $100 \mathrm{~m}$ range. Vice versa, plantation biodiversity increases by $20 \%$ where forests are within a $100-\mathrm{m}$ range. We identified the zones where forests and plantations are adjacent by buffer analysis. Afterwards, we increased (or decreased) biodiversity within the respective 100-m buffer zones. Several other methods exist to estimate biodiversity from land-use data. In order to benchmark the performance of our approach against other approaches, Braun and Koch (2016) not only implemented 
the hypothesis-based approach used here but also two other approaches. These included one approach based on the spectral variation hypothesis (Rocchini et al. 2004) and one based on a multivariate empirical model using a range of environmental data as independent variables to predict plant species richness (Altamirano et al. 2010). Compared to these two approaches, our hypothesisbased approach led to the most reliable results (see the "Results" section). A map of the resulting biodiversity estimates is shown in Fig. 3.

\section{Severe fire mask (SFM)}

In order to assess the areas burnt by the wildfires in 2017, CONAF (2017) has mapped damages according to Key and Benson (2006). They used Landsat and Sentinel 2 data to calculate the normalized burn ratio in pre- and postfire images. From the difference in both normalized burn ratios, they extracted a fire mask, which mapped the severely burnt pixels (severe fire mask, SFM). We used the SFM to assess burnt areas and to update the plant species richness estimate.

Fig. 3 Biodiversity estimate for the study site (following Braun and Koch 2016). Based on the combination of ecological biodiversity analysis and remote sensing analysis, an estimate for species richness in relation to the different land-use types of the study site is produced. Reddish areas represent places of low species richness; blue areas represent places of high species richness.

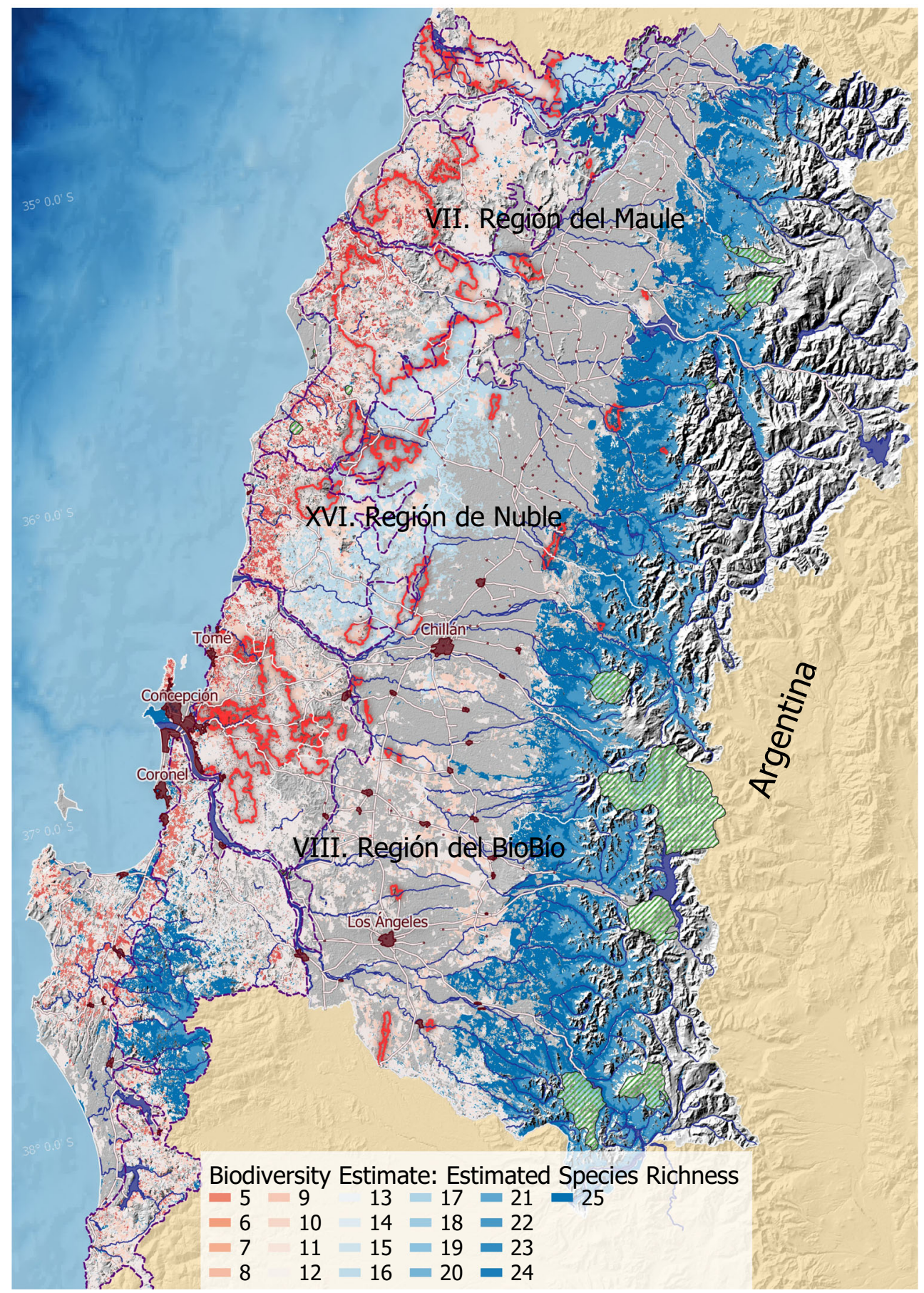




\section{Methods}

Within this section, the methods used in this study are outlined. The methods partly extend the methods of previous work (Sections "Biodiversity analysis (BDA)" and "Biodiversity estimate (BES)").

\section{Post land-use change biodiversity estimate (BES-2015)}

After conducting the study described in Braun and Koch (2016), we extended the BDA from 175 to 211 plots (mainly, to better assess plant species richness of mountainous areas) (see Fig. 1). For the sake of actuality, we added new Landsat data to provide a land-use map for 2015 (LUM-2015). The methodology of Braun and Koch (2016) was used to estimate plant species richness conditions in 2015 (after land-use change, before the wildfire). This dataset will be referred to as BES-2015 in the following.

\section{Postwildfire biodiversity estimate (BES-POSTFIRE)}

In order to assess the impact of the wildfire regarding plant species richness conditions, we additionally calculated a plant species richness map for the situation after the wildfire. In the LUM used in the approach of Braun and Koch (2016), burnt areas are not considered as no biodiversity surveys were conducted on such sites. However, we consider the clearcut class to have similar properties as areas affected by an intense wildfire. In terms of disturbance intensity and their vegetation-free conditions, clearcut and burnt sites resemble each other according to the logic of our ecological informatics approach, which combines land-use with biodiversity data. This simplified assumption allows us to model the immediate impact of the 2017 wildfires on plant species richness by creating a plant species richness map for the time directly after the fire using the same hypothesis-based approach described before (Braun and Koch 2016). At both sites, succession begins after the disturbance. Succession of both kinds of sites is ecologically different. These differences have an effect on the results and their interpretation, which will be discussed below.
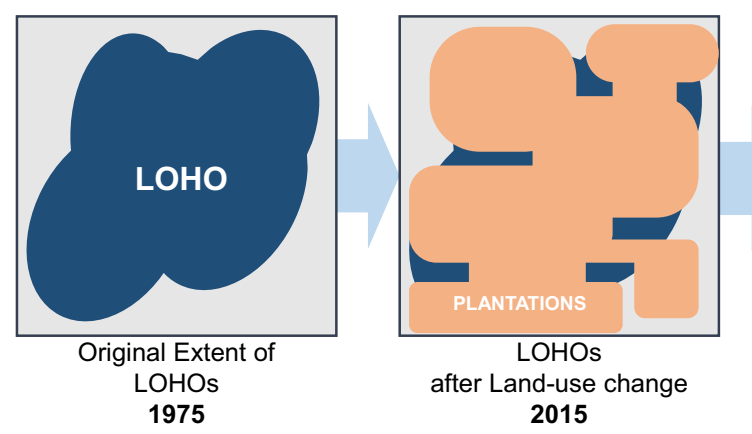

\section{Biodiversity hotspot identification}

Biodiversity hotspots can be identified on the basis of the spatial biodiversity estimates. In contrast to the biodiversity hotspot concept defined by Myers et al. (2000), who defined hotspots on a regional level (e.g., hotspot central Chile) based on species richness and endemism, we here define local plant species richness hotspots based on the plant species richness field data available for the study site. In the following, we will differentiate between two types of sites with high local plant species richness:

1. Primary local biodiversity hotspot (1_LOHO): places where the estimated biodiversity in the biodiversity maps (BES-1975, BES-2015, BES-postfire) according to Braun and Koch (2016) is larger than the $\mathrm{Q}_{0.75}$ quantile of the biodiversity estimates of the field relevés. The $\mathrm{Q}_{0.75}$ represents a species diversity $\geq 23$ within the 211 assessments in the biodiversity analysis (BDA).

2. Secondary local biodiversity hotspot (2_LOHO): places where the estimated biodiversity in the biodiversity maps (BES-1975, BES-2015, BES-postfire) according to Braun and Koch (2016) is larger than the $\mathrm{Q}_{0.55}$ quantile of the biodiversity estimates of the field relevés. The $\mathrm{Q}_{0.55}$ represents a species diversity $\geq 16$ within the 211 assessments in the biodiversity analysis (BDA).

These two types of biodiverse areas were identified in the biodiversity maps BES-1975, BES-2015, and BES-postfire. Hotspots were defined on the pixel level. However, since several geospatial analyses are easier using polygons, pixel-based results were vectorised in GIS. To make an example, postfire biodiversity hotspots were identified as

1_LOHO := BES_postfire $\geq 23$

2_LOHO := BES_postfire $\geq 16$

Results were then used as inputs to a habitat loss and fragmentation analysis based on landscape metrics.
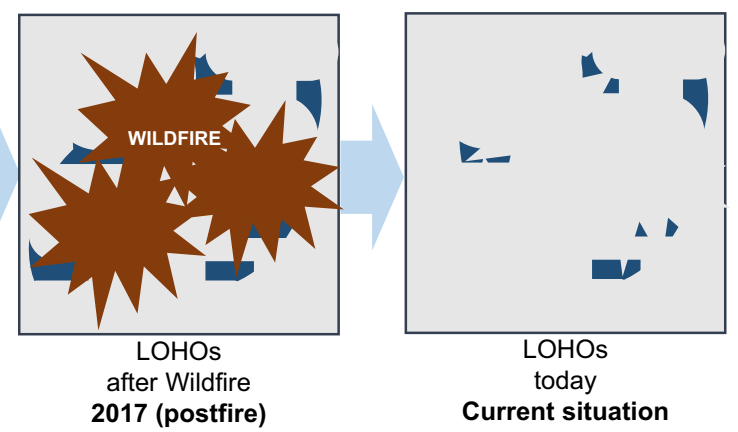

TEMPORAL TRAJECTORY

Fig. 4 Temporal trajectory of local biodiversity hotspots (LOHOs). Original extend of 1975: large and widespread biodiverse habitat. Landuse change in favour of plantations reduces this extent to smaller remnants. Wildfires, prone to ignite in plantations, further reduce LOHOs extend. Current situation: very small remnants of LOHOs. These are the conditions from which to design restoration concepts 


\section{Diverse habitat loss and fragmentation analysis}

Two processes leading to loss and fragmentation of near natural habitats were considered in this study. Firstly, large areas of near natural forests were lost or fragmented due to land-use changes since 1975 . Secondly, the 2017 wildfires have caused loss and fragmentation immediately after burning down the sites. Hence, we consider that the landscape has experienced a trajectory from initial conditions to the current state with impacts caused by land-use change and the 2017 wildfire (cf. Fig. 4).

Processes of habitat loss along the trajectory are analysed using spatial statistics. In order to assess habitat loss, two types of changes are computed. The first type (Percent_of 75) is the percentage of remaining numbers/areas of biodiversity hotspots in comparison to 1975. The second type (Percent_of_Previous) is the percentage of biodiversity hotspots remaining from the previous step (i.e., 1_LOHOs and 2_LOHOs of BES-(N) in comparison to BES-( $\mathrm{N}-1)$.

Processes of habitat fragmentation along the trajectory are analysed using landscape metrics calculated with FRAGSTATS (McGarigal et al. 2002). In FRAGSTATS, classes, background, and no data values have to be defined. Classes are parts of the landscape for which metrics are computed, background is part of the landscape for which no metrics are computed (but which may influence metrics computation for classes), and nodata is not part of the landscape (and does not influence the computation of the metrics). 1_LOHOs and 2_LOHOs were considered as two distinct classes; areas inside the landscape boundary with a lower diversity as $\mathrm{Q}_{0.55}$ were considered background. All other areas were considered as nodata. Landscape boundary was defined as the coastal range outline provided by Albers (2012). Note that numerous landscape metrics exist and have been compared in literature (e.g., Lustig et al. 2015; Uuemaa et al. 2013, and Fan and Myint 2014). We will here apply a set of landscape metrics earlier applied by Molina et al. (2015). In their study, they successfully applied these metrics within the study site of this report, and with a focus to a forest type that is frequent in the dataset of this study and applying the same type of remote sensing images (Landsat). Landscape metrics are well studied in ecological literature. Providing exhaustive explanations in the text would exceed the limits of this article. However, we provide the most relevant information in Table 2 (Appendix). Further details can be found in McGarigal et al. (2002).

In order to analyse the differences between BES-1975, BES-2015, and BES-postfire, changes of landscape metrics (met) were computed as

$\operatorname{chg}=\left(100 /\right.$ met $\left._{\mathrm{t} 1}\right) *$ met $_{\mathrm{t} 2}$,

where $\mathrm{t} 1$ and $\mathrm{t} 2$ are two points in time: (1) land-use change impact $(\mathrm{t} 1=1975, \mathrm{t} 2=2015)$, (2) fire impact $(\mathrm{t} 1=2015$, $\mathrm{t} 2=$ fire simulation). We categorised the changes represented by chg into five groups:

- 'strong loss': $\mathrm{t} 2$ yields less than $65 \%$ of the value of met that was yielded in $\mathrm{t} 1(\mathrm{chg}<65)$

- 'loss': t2 yields $65-95 \%$ of the value of met that was yielded in $\mathrm{t} 1 \quad(65 \leq \mathrm{chg}<95)$

- 'noch' (no change): t2 yields between $95 \%$ and $105 \%$ of met that was yielded in $\mathrm{t} 1(95 \leq \mathrm{chg}<105)$

- 'gain': $\mathrm{t} 2$ yields $105-135 \%$ of the value of met that was yielded in $\mathrm{t} 1 \quad(105 \leq \mathrm{chg}<135)$

- 'strong gain': $t 2$ yields more than $135 \%$ of the value of met that was yielded in $\mathrm{t} 1(135 \leq \mathrm{chg})$

Differences of patch metric values between different points in time were tested for significance. For our data, a normal distribution cannot be assumed. Therefore, we used a Kruskal-Wallis test with a significance level of $p=0.0005$. Differences in class or landscape metrics were not tested statistically, since only one value for each class or even for the entire landscape is computed.

\section{Results}

\section{Loss of biodiverse habitats}

The biodiversity analysis (BDA) clearly shows large differences between plantations and near natural forests: (1) the typical plantation of central Chile maintains a species richness which is reduced by $68 \%$ in comparison to the typical native forest (confidence level $p<0.05$ ), (2) the most species rich plantation holds a number of species which is lower than the least species rich native forest, (3) while near natural forests are dominated by native and endemic species, plantations are dominated by introduced and invasive species, and (4) the Pinus radiata D. Don plantations are the least biodiverse amongst the three considered plantation types ( $P$. radiata, Eucalyptus globulus LABILL., and Populus nigra L.) but are planted most frequently (Toro and Gessel 1999). The BDA further reveals dependencies between plantation type, age, and plant species richness. Regarding forests, differences, e.g., between mountainous and riparian forests, are revealed.

Biodiversity estimates were computed according to the methodology in the "Biodiversity estimate (BES)" section. The resulting plant species richness estimates were evaluated statistically. The result is a map with biodiversity estimates for all areas where forests, plantations, or scrublands were found in 2015. The correlation coefficient between estimated and true species richness (the latter based on the field data) yields an $\mathrm{R}^{2}$ of 0.73 and a root mean square error (RMSE) of 4.55 species (Braun and Koch 2016). Biodiversity hotspots were identified according to the methodology of the "Biodiversity hotspot identification" section. Processes of loss and 
Fig. 5 Land-use change, wildfires, and biodiversity in the study site. Mind figure rotation. Land-use in 1975 characterized by near natural forests with smaller plantation patches immersed. In 2017, near natural forests had been largely replaced by forest plantations and had suffered from wildfire impacts. Spatially explicit biodiversity model in three stages below (BES_1975, BES_2015, BES postfire)
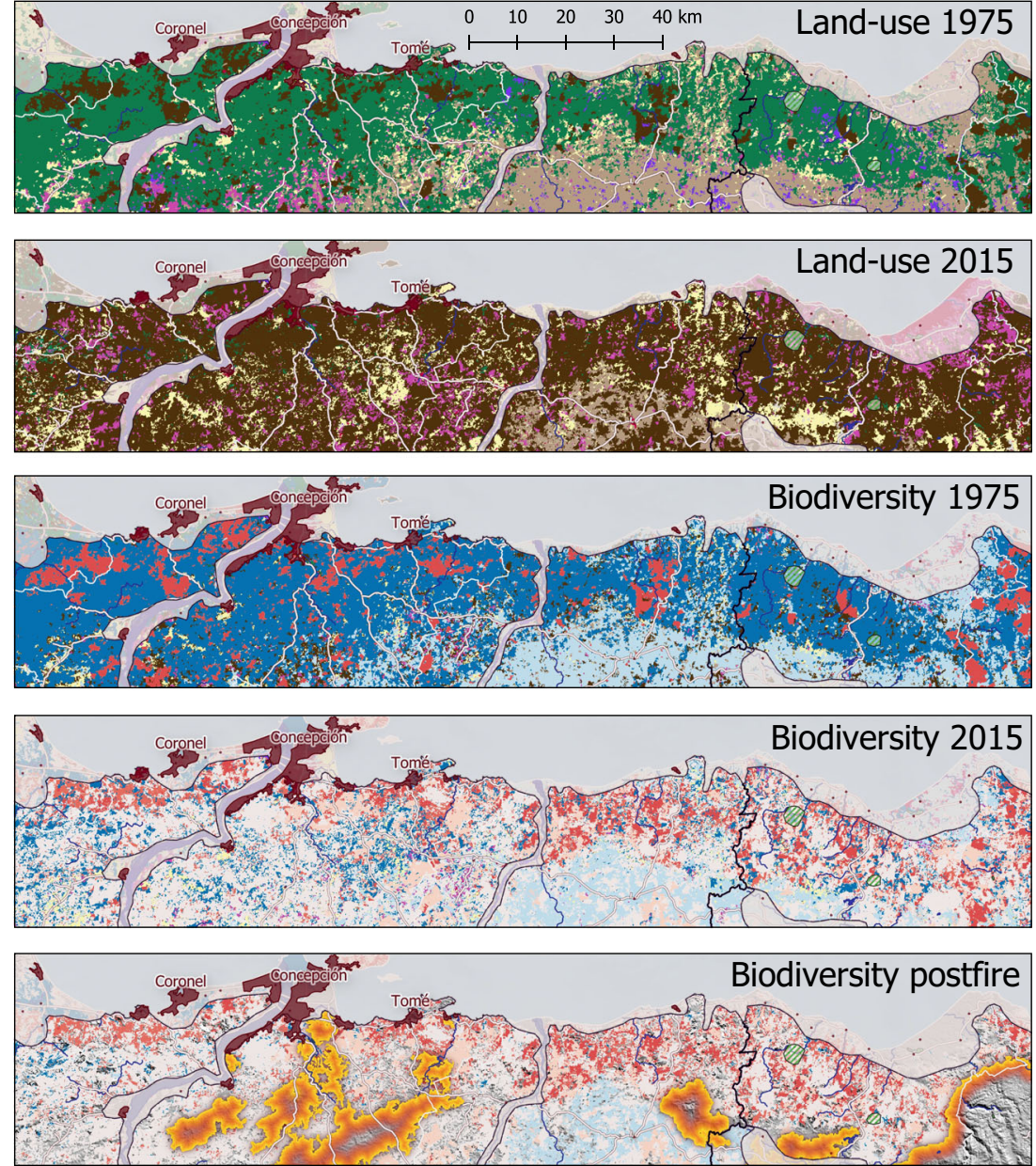

\begin{tabular}{|c|c|}
\hline Lan & d-use data \\
\hline & Near-natural forest \\
\hline & Commercial plantation \\
\hline & Agriculture \\
\hline & Shrublands \\
\hline & Clearcut \\
\hline & Urban areas \\
\hline & Water \\
\hline
\end{tabular}

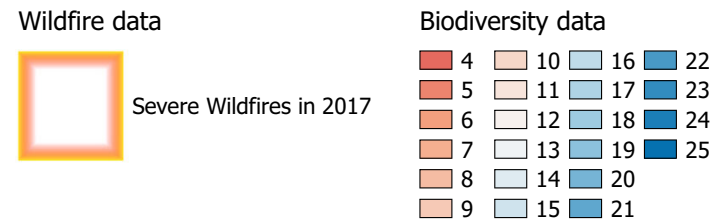

fragmentation were assessed using the methodology in the "Diverse habitat loss and fragmentation analysis" section. Trends in biodiverse habitats are related to land use change. The average accuracy of the LUM was $91.5 \%$ (Braun et al. 2012, 2014). The LUMs show a strong expansion of commercial plantations in the coastal range of central Chile following the introduction of the law DL 701 (after 1975). Accordingly, the maps show a substantial deforestation and forest fragmentation of near natural forests. (Fig. 2). Figure 5 shows the development of the complete landscape over time. The LUM-1975 and LUM-2015 reveal a pronounced change in the landscape configuration. A landscape with plantations immersed in a forest matrix transforms to forest remnants immersed in a plantation matrix. According to our approach, hardly any $1 \_$LOHO or 2 LOHO is found within the SNASPE natural reserves (which even seems to contain some plantations). BES-1975 shows a widespread cover of diverse habitat (mainly 1_LOHO); only the few plantation areas are low in species numbers. Consequently, after land-use change (BES-2015), the most diverse habitat area is lost, and low diversity habitats dominate.

The effects of the 2017 wildfires (BES-postfire) are, seemingly, a loss in some small habitats but hardly alter the landscape configuration. Most 2 LOHOs and 1 LOHOs after land-use change are found in the Nahuelbuta range (coastal range south of BioBío river) (Fig. 4). Here, no wildfire occurred. Outside of the Nahuelbuta range (cf. Table 3 Appendix), $13.9 \%$ of 2 LOHOs were (at least temporarily) lost during this single fire event. The respective loss for 1_LOHOs is $3.9 \%$.

Table 3 (Appendix) and Fig. 6 show the quantitative results of estimated loss of biodiverse habitats in the coastal range. 
Fig. 6 Results of spatial analysis of biodiverse habitat. Subfig. a Number of diverse habitat (dark blue: 1_LOHO, light blue: 2 LOHO) in 1975 (condition 1), after land-use change (condition 2), after wildfire (condition 3), Subfig. b Area of diverse habitat, Subfig. c Amount of diverse habitat remaining after each change (condition 1: land-use change, condition 2: wildfire), note that land-use change reduces amount of LOHOs significantly, while wildfire leave almost $100 \%$ of the patches before last change,

Subfig. d Area of diverse habitat remaining after each change
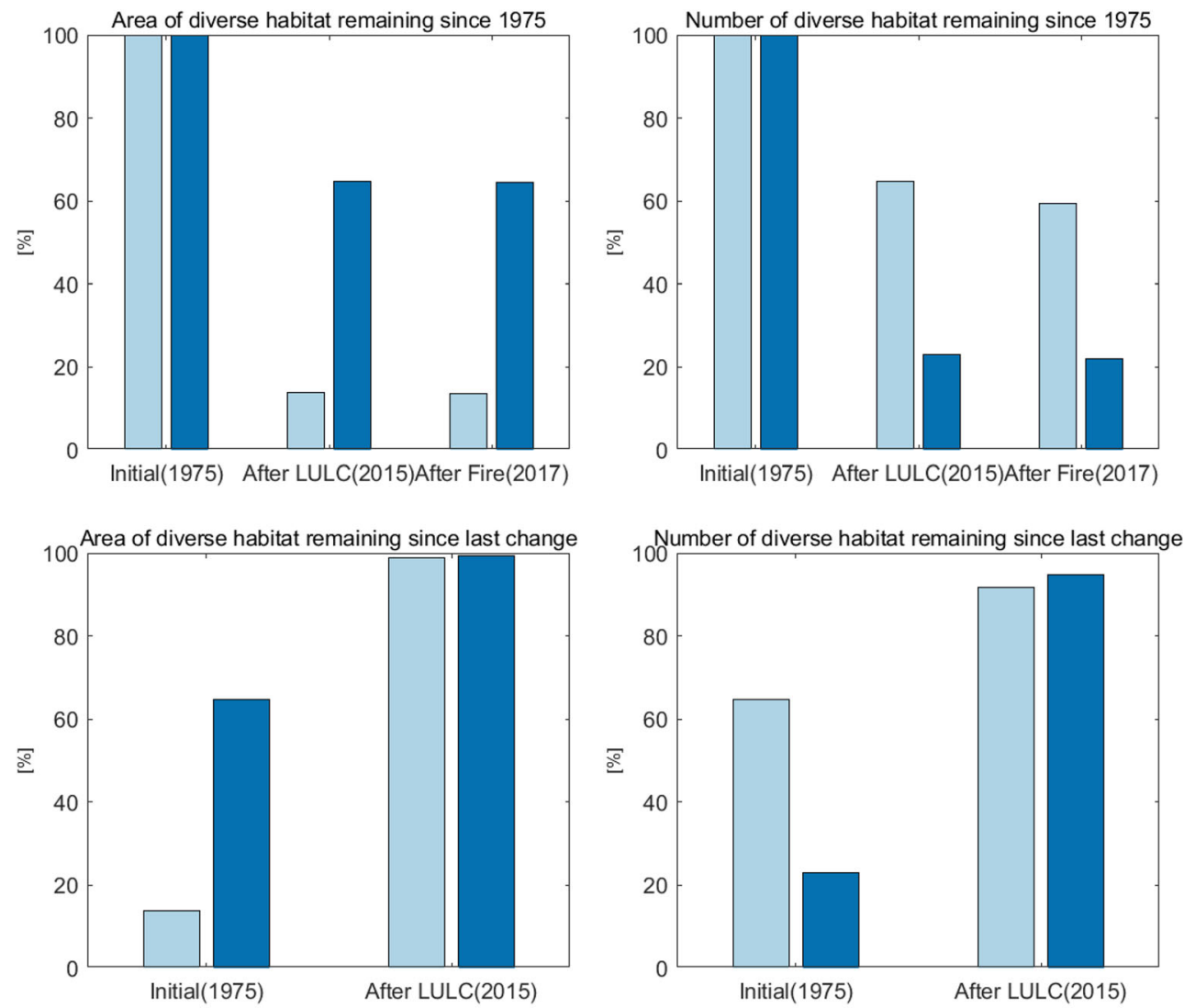

The Percent_of 75 value shows the changes of either the area or the number of hotspots in comparison to the situation in 1975; the Percent_of_Previous value illustrates the changes since the corresponding last time-step (BES-1975, BES2015, BES-postfire). The number of 1_LOHOs since 1975 (num_1_LOHO_Percent_of_75) reduced strongly due to lan - - use change. The reduction of num_1_LOHO_Percent_of 75 due to the 2017 wildfire is $-5.3 \%$. The area of 1 LOHOs since 1975 (area 1 LOHO Percent of 75) has experienced extremely pronounced losses due to land-use change $(-35.4 \%)$ but almost no losses due to wildfire.

Results differ for 2 LOHOs. The number of 2 LOHOs since 1975 (num_2_LOHO_Percent_of_75) experiences most extreme impacts due to land-use change $(-76.8 \%)$, but, in contrast to 1_LOHOs, only a low reduction $(-1.3 \%)$ due to wildfire. The area of 2_LOHOs since 1975 (area_2_LOHO_Percent_of_75) suffers from strong reduction due to land-use change but almost no reduction due to fire.

\section{Fragmentation of biodiverse habitats}

Figure 5 shows the results regarding habitat fragmentation. It becomes obvious from a comparison between LUM-1975 and LUM-2015 that forest areas and diverse habitats have become seriously fragmented. The map and the quantitative data in Tables 3 and 4 (Appendix) exemplify these developments clearly. In BES-1975, large and connected 1_LOHOs were found in the coastal range. 2 LOHOs were better connected as well. Land-use change (BES-2015) has fragmented both and furthermore, altered the spatial configuration. 1_LOHOs and 2_LOHOs are no longer separated; instead, many 2 LOHOs now form the ecotones between remnant 1_LOHOs and nondiverse habitats. The wildfires did not significantly increase fragmentation (BES-postfire) mostly because the landscape was already severely fragmented before.

The results regarding the class metrics are summarized in Table 4 (Appendix). Regarding area and edge metrics, the LPI, TE, and ED show strong losses as induced by land-use change. In contrast, the impacts induced by the 2017 wildfires 
are mild. Similar results are observed for core habitat indices. TCA, CPLAND, and DCAD show that land-use change reduced the largest amount of core habitat, while the effects of the 2017 wildfires are less pronounced. Regarding shape metrics, PARA_MN shows minor losses only for 2_LOHOs caused by land-use change. Regarding contrast metrics, TECI of 1_LOHOs hardly changed due to the land-use change or fire. TECI values of 2 LOHOs increase after land-use change. The aggregation metric ENN_MN is increased by land-use change but not significantly altered by fire.

The results regarding the landscape metrics are summarized in Table 5 (Appendix). It is important to stress that the analysis has considered 1_LOHOs and 2_LOHOs as classes of the landscape, while less diverse habitats were considered as background. Hence, landscape metrics describe the overall situation of diverse habitats against the background of less diverse habitats (mainly commercial plantations, degraded scrublands, and unforested sites). At the landscape level, the impact of the 2017 fire is more pronounced. Considering all diverse habitats, land-use changes caused the majority of losses of biodiverse habitats, but the 2017 wildfires still caused a remarkable extra damage regarding the number of patches (NP) and the patch density (PD). The MESH metric indicates a reduced effective patch and mesh size after land use change; the 2017 wildfires further reduce the values of this metric. Regarding landscape aggregation, at first, a pronounced increase in Euclidean nearest neighbour distance (ENN_MN) induced by land-use change has to be noted. The wildfires did not increase ENN_MN distance significantly. The splitting index (SPLIT) shows similar trends to ENN_MN and proves that at the landscape level, biodiverse habitats were split up notably by land-use change but remained at that level after the fires.

The results regarding the most indicative patch metrics are visualized in Fig. 7. It shows the distribution of the AREA (log transformed) values of patches. As can be seen, since 1975 particularly small and middle sized patches of 1_LOHOs were lost. The changes in ENN distribution reveal important changes in the landscape. The amount of 2 LOHO and 1_LOHO patches with close nearest neighbours is significantly reduced by land-use change, isolating patches from one another. The wildfires did not alter this situation.

Boxplots for the patch metrics are given in Fig. 8. First, it should be noted that most metrics show non-Gaussian, skewed distributions, characterized by a high number of outliers. Land-use change induces changes in patch metrics that indicate strong habitat loss and fragmentation (differences between first and second point in time). In contrast, the wildfires do not alter patch metrics distributions (differences between second and third point in time). Table 6 (Appendix) shows the results of the Kruskal-Wallis significance tests of differences in patch metrics. With the exception of AREA, PERIM and PARA for 1_LOHOs, and PERIM and PROX for 2 LOHOs, land-use change (differences between the results of 1975 and 2015) has caused highly significant changes for all patch metrics calculated. In contrast, with the exception of SIMI, changes caused by the wildfires of 2017 (differences between the results of 2015 and 2017) were all not significant.

\section{Discussion}

\section{Loss of diverse habitats}

Our two classes of diverse habitats (1_LOHOs - highest diversity/2_LOHOs_-high diversity) were differently affected by land-use change and the wildfires of 2017. In general, 1_LOHOs mainly lost area while 2_LOHOs were reduced in numbers (an exception are small 1_LOHOs cf. Fig. 7b, which is explained below). This observation is explained by the definition of 1_LOHOs and 2_LOHOs. 1_LOHOs typically comprise core habitats of larger forests (as only in such habitats very high diversity numbers can be reached) while 2_LOHOs are ecotones with less diverse habitats. With progressing land-use change, 1_LOHOs have massively lost areas starting from their borders, while often some remainder of the core habitat still persists. On the other hand, losses of area for the 2_LOHO class are slowed down, since many areas that used to belong to the core of 1_LOHOs are now flanked by plantations, which reduces their plant species richness, pushing them into the 2 LOHO class. The reduction of area of diverse habitats is generally conceived as a threat to animal species depending on large continuous habitats. One example for such a species is the Chilean Pudu (Pudu puda, MolinA), cf. Weber and Gonzalez (2003).

Regarding drivers of habitat loss, land-use changes had more severe impacts than the 2017 wildfires did (if their effects are assumed to be permanent). Due to the incentives for the establishment of forest plantations (i.e., the subsidies granted by the law DL 701 and the favourable world market prices), land-use change has systematically diminished diverse habitats from 1975 (Miranda et al. 2017). A side effect of this transition from natural forests to plantations was a notably increased wildfire risk due to the high ignitability of some of the plantation species (e.g., Carmona et al. 2012; Gómez-González et al. 2019). Even though we found the single fire event examined here to play an inferior role in the reduction of current plant species richness compared to the land-use change of the last decades, impacts of the 2017 and future wildfires should not be underrated for several reasons. Firstly, single fires burn remaining 1 LOHO and 2_LOHO area in a short time period (e.g., in 2017 the area outside of 
Fig. 7 Analysis of the distribution of landscape metrics of diverse habitat and how it changes along the trajectory. Barplots of 12 classes for each metric. Subfig. a $\log ($ area $)$ metric of 2_LOHO, Subfig. b $\log$ (area) metric of 1 LOHO, Subfig. c para metric of 2_LOHO, Subfig. d $\log (\mathrm{enn})$ metric of 1 LOHO, Subfig. e para metric of 2 LOHO, Subfig. $\mathbf{f}$ $\log (\mathrm{enn})$ metric of 1 LOHO.

Note that most metrics change quantitatively, but not qualitatively (i.e., distributions remain similar)
Log area metric of secondary biodiversity hotspots
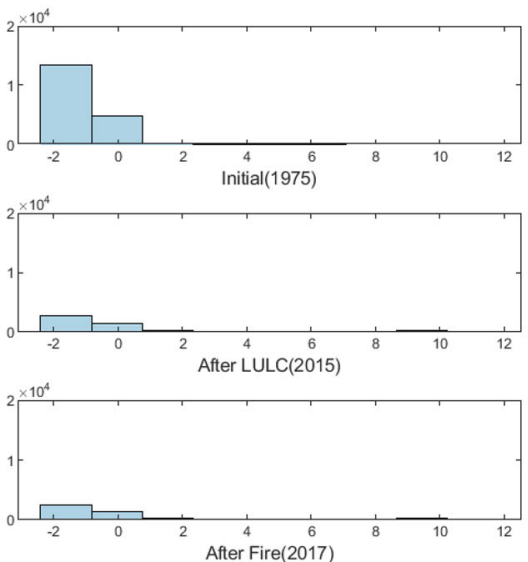

Perimater/area metric of secondary biodiversity hotspots
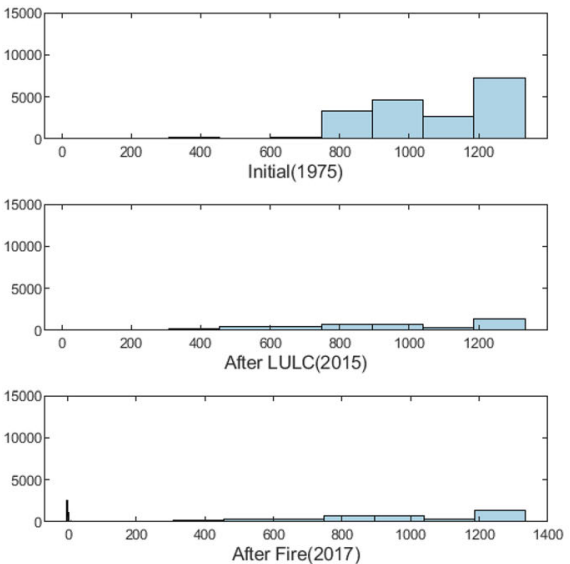

Log Nearest Neighbour metric of secondary biodiversity hotspc Log Nearest Neighbour metric of primary biodiversity hotspots
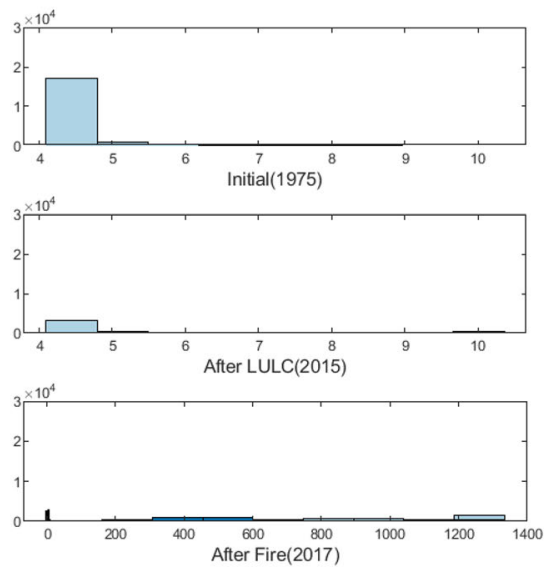

Log area metric of primary biodiversity hotspots
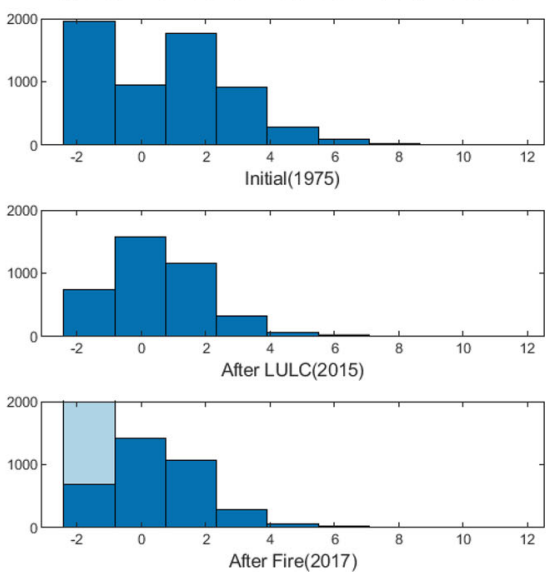

Perimater/area metric of primary biodiversity hotspots
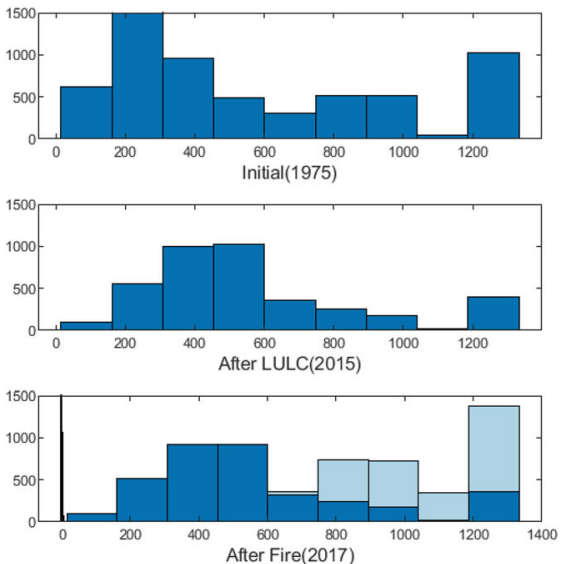
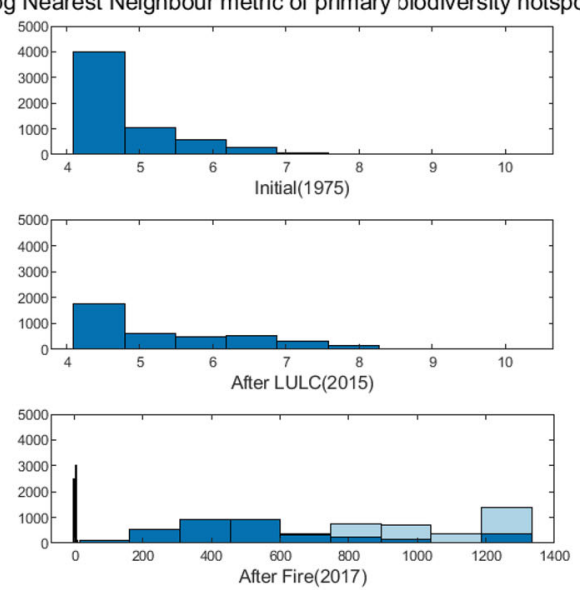

Nahuelbuta). Although these sites may have natural recovery potentials, land-use change effects may prevent recovery. Secondly, wildfires, mainly caused by plantation forestry and agriculture, are assumed to become more frequent in the face of climate change (McWethy et al. 2018). Since the fire adaptation of the Chilean matorral is not entirely understood (Gómez-González et al. 2017), it remains to be investigated whether there is resistance to accumulated effects of multiple wildfires. Thirdly, 1_LOHOs and 2_LOHOs are defined on the basis of plant species richness. Although plant communities may potentially recover from wildfire, there are other organisms potentially threatened by wildfire. For species whose survival depends on metapopulation ecological effects such as the rescue effect, the loss of hotspots may have consequences. 

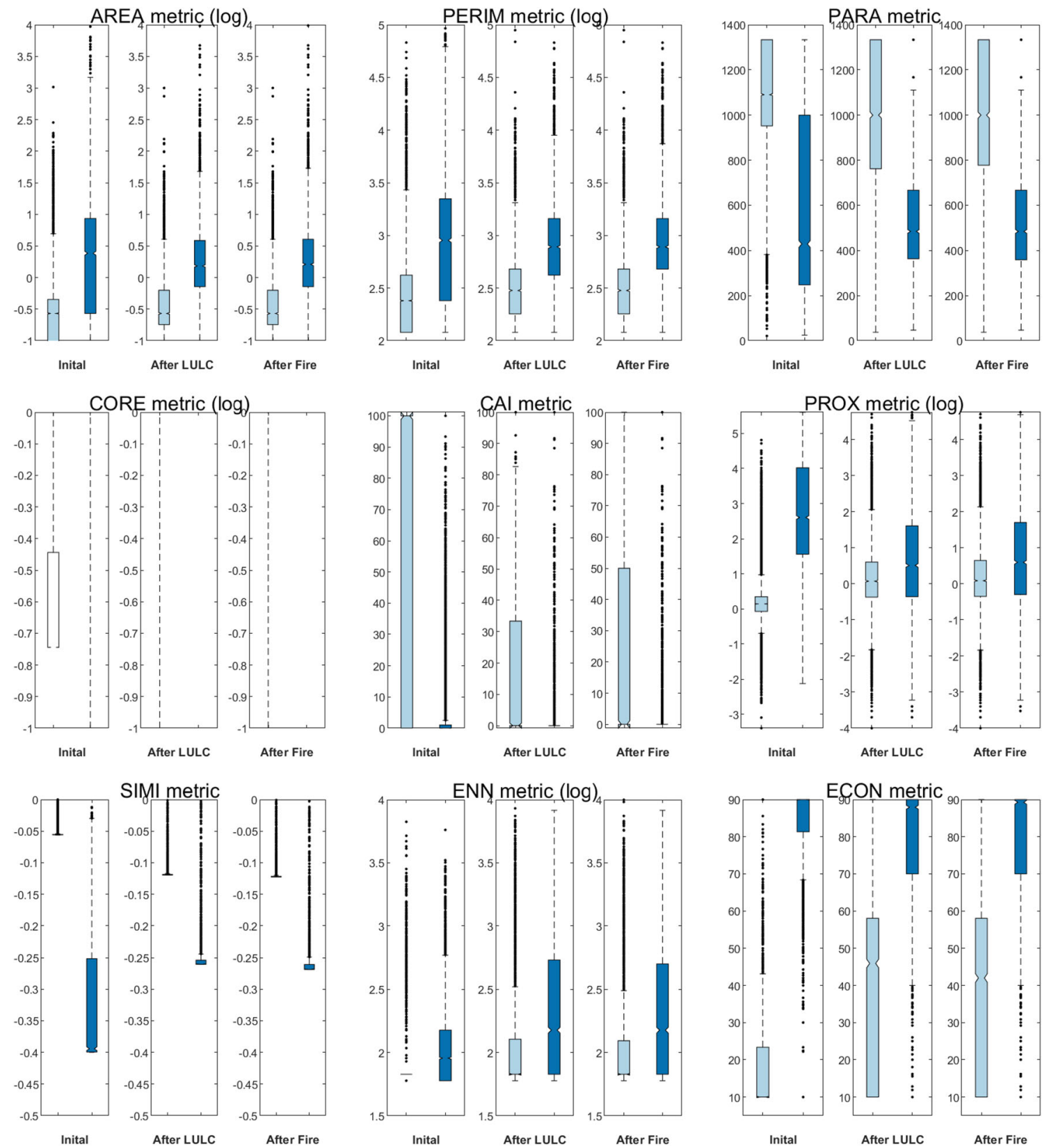

Fig. 8 Boxplots for patch metrics. Cond 1: initial conditions before land use change and wildfire, cond 2: conditions after land use change, cond 3: conditions after wildfire. Some patch metrics are log transformed (AREA,

PERIM, PROX, ENN, CORE) other are shown with untransformed values (PARA, CAI, ECON, SIMI)

A reduction in the number of hotspots could be as threatening to the survival of such species as a reduction in area is to species that need large, intact habitats. Even if the burnt areas would recover completely (which is unlikely as further discussed before), the transition time until the habitats are restored may pose severe challenges for some species depending for example on old-growth natural forests.

From a conservation perspective, the 2017 wildfires are relevant since they cleared many vegetated areas formerly used as plantations. Gómez-González et al. (2018) have called this situation a "window of opportunity". Burnt plantation areas could be left without restocking in order to allow for natural vegetation recovery. This would constitute a reactive conservation approach sensu Brooks et al. (2006). Alternatively, the big wildfires from 2017 at least potentially could serve as "ground zero" to begin with proactive environmental restoration. This may be considered a more promising approach as natural vegetation recovery may be problematic due to the competition of the fire-adapted plantation species, which also recover naturally. Although experimental 
restoration concepts to reestablish native forests in plantation areas exist (Kremer et al. 2020), large-scale restoration of native forests is still no important practice in Chile.

Not using this window of opportunity is likely to result in a further reduction of biodiversity-rich areas in central Chile. Maintaining and further expanding plantation forests stocked with fire-adapted species will likely continue to alter the natural fire regime and support the spread of invasive species including the plantation tree species themselves. Strong relations between invasion success and altered fire regimes (partly driven by the invasive species themselves) have been observed in other parts of the world, including areas where land-use change in vegetated areas was less dramatic than in Chile, as for example in California (Brooks et al. 2004). Changing such systems back to the original state becomes increasingly challenging over time (Brooks et al. 2004). Furthermore, the situation in most vegetated ecosystems in central Chile is not directly comparable to more fire-prone ecosystems with a stable fire regime where the maintenance of biodiversity depends on the regular occurrence of fire, and fire is de facto a key driver of biodiversity (He et al. 2019). In central Chile, biodiversity hotspots in terms of vascular species richness are connected to old growth native forests, which have not been affected by severe fires or other stand-replacing disturbances for a long time (Braun 2013; Braun et al. 2017). Such very low fire frequencies are not representing the current situation in Chile, but it seems likely that the current fire regime (at least in plantation-dominated areas) only exists for a few decades and is a direct result of the land-use change processes, climate change, and a generally increased fire ignition risk due to anthropogenic activities (McWethy et al. 2018; Gómez-González et al. 2019). Gonzalez et al. (2005) indicate an increase in fire occurrence after the Euro-Chilean settlement after 1880, but further research is required. It is known from other parts of the world that such an alteration of a fire regime of a region can lead to situations, to which the native vegetation is not adapted to (Keeley et al. 2011). This can result in notable alterations to community structure and a substantial risk of extinction for endemic species (Driscoll et al. 2010 and references herein).

\section{Development of landscape metrics}

In addition to analysing the number and area of biodiverse habitat, we examined trends in landscape metrics under land-use change and the occurrence of the large wildfires in 2017. Our results pointed out that land-use change is the principal driver not only of habitat loss but also of habitat fragmentation. Land-use change has significantly fragmented the total habitat area, edge habitats, and core habitats. It has isolated habitat patches from one another, increasing the distance towards the nearest neighbouring habitat patch. No significant changes on the shape of patches were induced. The fire did not aggravate this situation significantly; its main effect was to further reduce habitat availability while it had only limited effects on fragmentation within an already severely fragmented landscape. Edge contrasts represented by TECI is hardly altered by land-use change and fire for 1_LOHOs. This is due to the fact that 1_LOHOs are surrounded by 2_LOHOs, which show a high similarity, yielding low contrasts as measured by TECI.

Fragmentation was already severe before the 2017 wildfires. Hence, despite their large extent, 2017 wildfires had few additional effects. Today's situation is worrisome, since both edge and core habitats are drastically reduced, putting species typical for both types of habitats under pressure (cf. Acosta-Jamett and Simonetti 2004).

The patch metrics indicated a loss of small 1_LOHOS (Fig. $7 b$ ). This is largely explained by impacts on riparian vegetation. In 1975, wide riparian corridors stocked with natural vegetation existed. In such corridors, plant species richness is high (cf. Braun 2013). Hence, such areas formed small 1_LOHOs according to our definition. Then, land-use change decreased the width of corridors, e.g., by destruction of the riparian corridors' margins during harvest of adjacent plantations (Rojas et al. 2020). The currently remaining corridors are typically only a couple of metres wide. It is questionable whether such narrow corridors effectively connect habitat patches to prevent species extinction (Damschen et al. 2006; Fagan et al. 2016). Hence, the former 1_LOHO areas in riparian corridors are often degraded to the 2_LOHO level. The loss of these small 1_LOHOs along rivers may particularly be problematic for amphibians (Solís et al. 2010; Veloso 2006).

Another trend revealed by the landscape metrics was that land-use change from 1975-2015 shifts the area distribution towards considerably smaller 1_LOHOs. On the other hand, 2_LOHOs never experienced significant changes regarding area distribution, which also relates to their definition as the decisive plant species richness levels often occur in patches of a certain size. We did not observe any trend with respect to the shape of habitat patches as indicated by the perimeter-area ratio (PARA).

The boxplots and Kruskal-Wallis tests on patch metrics consistently underline our main finding. While land-use change has altered the landscape configuration of biodiverse habitat patches significantly, the 2017 wildfires did not have any pronounced additional effect. The differences between patch metrics between the second and third points in time (i.e., the wildfire effects) were almost never significant. As an exception, SIMI has been significantly reduced by the wildfire. Note that burnt areas are not considered as patches in our patch metric analysis. Hence, any patch in the vicinity of a 1 LOHO and 2 LOHO, affected by fire, is deleted from the analysis. Consequently, the wildfire obviously reduced size and proximity of patches in the vicinity of $1 \_$LOHOs and 2_LOHOs. 


\section{Limitations of the presented approach}

The presented approach faces some limitations which should be addressed in future studies. A first limitation is that we used vascular plant species richness as sole indicator for biodiversity. While this has been proven to be a valid approach in some earlier studies (Brunbjerg et al. 2018), there might still be some limitations. As landscape ecological theory shows (Turner and Gardner 2015), biodiversity does not only depend on local variables but also on landscape variables such as patch size, connectivity (increasing effect rescue), or the border length and density. Preliminary assessments correlating patch metrics at the surveyed plots with their plant species richness show some interesting correlations (cf. Appendix A) but need further investigation.

An important limitation of our study is that we assumed that the situation after a high-severity wildfire is comparable to a clear-felled areas in terms of the prevailing number of plant species. We believe that this assumption is acceptable for the situation immediately after a wildfire. However, the vegetation recovery in the years after the fire may differ widely depending on the prefire land cover and the site history (Puerta-Piñero et al. 2012). Most natural ecosystems in Central Chile seem to have a quite good ability to recover after a wildfire, mostly due to resprouting abilities of many species (Castillo et al. 2020). However, this recovery ability may also be affected by additional pressures arising from invasive species or land-use changes implemented after the fire. Given the massive expansion of plantation species with high invasion potential over the last decades and the still-persisting will to convert more land to commercial plantations, it is likely that a notable part of the natural ecosystems burned during the 2017 wildfires will not fully recover if no actions are taken. Particularly, natural Nothofagus forests with dense canopies are likely to have maintained a self-protection mechanism against invasion of light demanding plantation species such as Pinus radiata (Bustamante and Simonetti 2005). After the wildfire, this protection does not exist anymore, and given the omnipresence of seed sources in close proximity, it is likely that a notable proportion of the burnt natural forests will struggle to fully recover due to invasions by Pinus radiata and other fast growing, light-demanding invasive species. We, for example, observed dense carpets of Pinus radiata seedlings in several areas stocked with natural forests before the wildfire during a recent field campaign (unpublished data and results). Just as importantly, there is concern that burnt native forest remnants within plantations are not left to natural succession. Instead, they could be replanted with Pinus and Eucalyptus when the plantation itself is restocked (unpublished data and results). Future studies following a similar approach as we did here should consider such processes to allow for a more precise prediction of the biodiversity development after major wildfire events.
Finally, the examination of wildfires' effects on biodiversity or plant species richness was here restricted to the fire season of 2017. It is known that fires already had an influence on the biodiversity of Central Chile before these large fires occurred (Úbeda and Sarricolea 2016). Hence, a further means to improve our plant species estimates on landscape level could be to also consider the fire or disturbance history of the landscape. While it is impossible to reconstruct the disturbance history with all details, there are remote sensing-based approaches to document at least the majority of standreplacing disturbances over the last 40 years. Hence, variables such as "time since last disturbance" and "number of disturbances over the last 40 years" could be examined as additional variables for explaining plant species richness patterns. Furthermore, simulations might provide some insights. For instance, Bond and Keeley (2005) compared a hypothetical fire-free landscape comprising potential natural vegetation with the actual landscape. However, such approaches are beyond the scope of this article.

\section{Consequences for a landscape restoration concept}

Summarizing the discussion, wildfires such as the one occurring in 2017 could be considered a "window of opportunity" as suggested by Gómez-González et al. (2017). They argue that the vast areas burned down within former plantations could be used to restore a more natural landscape in central Chile. Our analyses support this finding. They show that wildfires are not the main source of potentially permanent losses of biodiverse habitats, but could be part of a solution for restoration. Quantitatively, most areas burned down within plantations. If there were a public-private dialogue on environmental governance aimed at restoring near-natural ecosystems, the areas opened by fire could be used for this purpose. However, this window of opportunity is already closing again because forest companies have been quick in replanting fire-affected areas with Pinus and Eucalyptus (as the authors could witness during a fieldtrip, only eight months after the fires). Furthermore, from field visits, it seems that plantations have even been extended to burnt 1_LOHOs and 2_LOHOs. Thus, currently, there is no succession of native forest but further replacement. If the biodiversity hotspot in central Chile is meant to be preserved, alternatives to the currently ongoing measures have to be discussed. Our approach could be used to simulate the potential benefits of, e.g., establishing additional natural reserves or increasing connectivity by near-natural forest corridors between plantations. Such simulations could support restoration planning and would constitute a valuable contribution to biodiversity conservation in Chile. A comprehensive restoration concept should take account of the differing succession processes on clearcut and burnt areas though. 


\section{Conclusion and outlook}

In this study, we examined the influence of land-use change (1975 to 2015) and the 2017 wildfires on the occurrence of biodiverse habitats in central Chile. Our analysis has clearly pointed out that land-use change had far more severe consequences to the biodiversity hotspot central Chile, than the 2017 wildfires did. Habitat loss and fragmentation due to land-use change exceed the impact of the wildfires. The impact of wildfire is qualitatively different to land-use change (in central Chile) since rather than reducing large areas of biodiverse habitat, they threaten the last remnants of near natural forests. Most importantly, wildfires and land-use change can indeed coerce to threaten the biodiversity hotspot in Chile. Forest remnants become even more threatened since wildfires are more prone to incinerate within plantations, which nowadays are often in close proximity of remnants (McWethy et al. 2018). This may lead to seedling establishment of $P$. radiata in burnt native forest, hampering natural succession. Furthermore, plantation management may simply replace former native forests.

In future studies, the methodology used by Braun and Koch (2016) and in this study can be applied to simulate different strategies for ecological restoration by updating and reinitializing the biodiversity estimation model using synthetically altered land-use maps. Although succession and metapopulation effects (such as rescue effects) are not included in the model, it could provide a reasonable estimate for immediate impacts on population and community ecology. Developing restoration concepts is crucially required in central Chile, since land-use change has destroyed almost the entire extent of diverse habitats in the coastal range and future wildfires (especially when becoming more frequent or intense under climate change) may be the razorblade to eliminate the last remainders.

The described combination of effects of human exploitation and natural hazard may not be limited to the hotspot central Chile. It could also be a problem in other regions, where human land-use and (human-induced) fire coerce detrimental effects, like in the Brazilian Amazon (Cochrane and Schulze 1998), the Maputaland region (Gaugris and Van Rooyen 2010), the Caucasus (Osepashvili 2012), Indomalaya, where human overuse promotes forest fires (Dawson 2001) or Sri Lanka, where wildfires occur within plantations, potentially impacting native vegetation remnants (Ariyadasa 2000).

Supplementary Information The online version contains supplementary material available at https://doi.org/10.1007/s10113-021-01756-4 .

Funding Open Access funding enabled and organized by Projekt DEAL.
Open Access This article is licensed under a Creative Commons Attribution 4.0 International License, which permits use, sharing, adaptation, distribution and reproduction in any medium or format, as long as you give appropriate credit to the original author(s) and the source, provide a link to the Creative Commons licence, and indicate if changes were made. The images or other third party material in this article are included in the article's Creative Commons licence, unless indicated otherwise in a credit line to the material. If material is not included in the article's Creative Commons licence and your intended use is not permitted by statutory regulation or exceeds the permitted use, you will need to obtain permission directly from the copyright holder. To view a copy of this licence, visit http://creativecommons.org/licenses/by/4.0/.

\section{References}

Abella SR, Fornwalt PJ (2015) Ten years of vegetation assembly after a North American mega fire. Glob Chang Biol 21(2):789-802. https:// doi.org/10.1111/gcb. 12722

Acosta-Jamett G, Simonetti JA (2004) Habitat use by Oncifelis guigna and Pseudalopex culpaeus in a fragmented forest landscape in central Chile. Biodivers Conserv 13(6):1135-1151. https://doi.org/10. 1023/B:BIOC.0000018297.93657.7d

Alaniz AJ, Galleguillos M, Perez-Quezada JF (2016) Assessment of quality of input data used to classify ecosystems according to the IUCN Red List methodology: The case of the central Chile hotspot. Biol Conserv 204:378-385. https://doi.org/10.1016/j.biocon.2016.10. 038

Albers C (2012) Coberturas SIG para la enseñanza de la Geografía en Chile. www.rulamahue.cl/mapoteca. Universidad de La Frontera. Temuco

Altamirano A, Field R, Cayuela L, Aplin P, Lara A, Rey-Benayas JM (2010) Woody species diversity in temperate Andean forests: the need for new conservation strategies. Biol Conserv 143(9):2080 2091. https://doi.org/10.1016/j.biocon.2010.05.016

Andersson K, Lawrence D, Zavaleta J, Guariguata MR (2016) More trees, more poverty? The socioeconomic effects of tree plantations in Chile, 2001-2011. Environ Manag 57(1):123-136. https://doi. org/10.1007/s00267-015-0594-x

Ariyadasa KP (2000) Fire situation in Sri Lanka. In: FAP (2000). Global forest fire assessment 1990-2000, Rome

Armesto JJ, Bustamante-Sanchez ME, Diaz MF, González ME, Holz A, Nuñez-Avila M, Smith-Ramirez C (2009) Fire disturbance regimes, ecosystem recovery and restoration strategies in Mediterranean and temperate regions of Chile. Fire Effects on Soils and Restoration Strategies. Science Publishers, Enfield, New Hampshire, pp 537567

Asaad I, Lundquist CJ, Erdmann MV, Costello MJ (2017) Ecological criteria to identify areas for biodiversity conservation. Biol Conserv 213:309-316. https://doi.org/10.1016/j.biocon.2016.10.007

Assal TJ, González ME, Sibold JS (2018) Burn severity controls on postfire Araucaria-Nothofagus regeneration in the Andean Cordillera. J Biogeogr 45(11):2483-2494. https://doi.org/10.1111/ jbi. 13428

Banfield CC, Braun AC, Barra R, Castillo A, Vogt J (2018) Erosion proxies in an exotic tree plantation question the appropriate landuse in Central Chile. Catena. 161:77-84. https://doi.org/10.1016/j. catena.2017.10.017

Bitterlich PF (2001) Manual de derecho ambiental chileno. Editorial Jurídica de Chile, Santiago de Chile

Bond WJ, Keeley JE (2005) Fire as a global 'herbivore': the ecology and evolution of flammable ecosystems. Trends Ecol Evol 20:387-394. https://doi.org/10.1016/j.tree.2005.04.025 
Bowd EJ, Lindenmayer DB, Banks SC, Blair DP (2018) Logging and fire regimes alter plant communities. Ecol Appl 28(3):826-841. https:// doi.org/10.1002/eap.1693

Bowman DMJS, Williamson GJ, Prior LD, Murphy BP (2016) The relative importance of intrinsic and extrinsic factors in the decline of obligate seeder forests. Glob Ecol Biogeogr 25:1166-1172. https:// doi.org/10.1111/geb.12484

Braun AC (2013) Eine geoökologische und fernerkundliche Prozessanalyse zum Risikozusammenhang zwischen Landnutzung und Biodiversität an einem Beispiel aus Chile. KIT Scientific Publishing, Karlsruhe

Braun AC, Koch B (2016) Estimating impacts of plantation forestry on plant biodiversity in southern Chile - a spatially explicit modelling approach. Environ Monit Assess 188(10):1-21. https://doi.org/10. 1007/s10661-016-5547-1

Braun AC, Vogt J (2014) A multiscale assessment of the risks imposed by plantation forestry on plant biodiversity in the hotspot Central Chile. Open J Ecol 4(16):1025. https://doi.org/10.4236/oje.2014.416085

Braun AC, Weidner U, Hinz S (2012) Classification in high-dimensional feature spaces - assessment using SVM, IVM and RVM with focus on simulated EnMAP data. IEEE J Sel Top Appl Earth Observ Remote Sens 5(2):436-443. https://doi.org/10.1109/JSTARS.2012. 2190266

Braun AC, Rojas C, Echeverria C, Rottensteiner F, Bähr HP, Niemeyer J, Aguayo Arias M, Kosov S, Hinz S, Weidner W (2014) Design of a spectral-spatial pattern recognition framework for risk assessments using Landsat data - a case study in Chile. IEEE J Sel Top Appl Earth Observ Remote Sens 7(3):917-928. https://doi.org/10.1109/ JSTARS.2013.2293421

Braun AC, Troeger D, Garcia R, Aguayo M, Barra R, Vogt J (2017) Assessing the impact of plantation forestry on plant biodiversity: a comparison of sites in Central Chile and Chilean Patagonia. Glob Ecol Conserv 10:159-172. https://doi.org/10.1016/j.gecco.2017.03. 006

Braun-Blanquet J (1964) Pflanzensoziologie. 3 Aufl. 865 pp. Wien-New York. https://doi.org/10.1007/978-3-7091-8110-2

Brooks ML, D'Antonio CM, Richardson DM, Grace JB, Keeley JE, DiTomaso JM, Hobbs RJ, Pellant M, Pyke D (2004) Effects of invasive alien plants on fire regimes. BioScience 54(7):677-688. https://doi.org/10.1641/0006-3568(2004)054[0677:EOIAPO]2.0. $\mathrm{CO} ; 2$

Brooks TM, Mittermeier RA, da Fonseca GA, Gerlach J, Hoffmann M, Lamoreux JF, Mittermeier CG, Pilgrim JD, Rodrigues AS (2006) Global biodiversity conservation priorities. Science 313(5783):58 61. https://doi.org/10.1126/science.1127609

Brunbjerg AK, Bruun HH, Dalby L, Fløjgaard C, Frøslev TG, Høye TT, Goldberg I, Læssøe T, Hansen MDD, Brøndum L, Skipper L, Fog K, Ejrnæs R (2018) Vascular plant species richness and bioindication predict multi-taxon species richness. Methods Ecol Evol 9(12):2372-2382. https://doi.org/10.1111/2041-210X.13087

Bustamante RO, Castor C (1998) The decline of an endangered temperate ecosystem: the ruil (Nothofagus alessandrii) forest in central Chile. Biodivers Conserv 7(12):1607-1626. https://doi.org/10.1023/A: 1008856912888

Bustamante RO, Simonetti JA (2005) Is Pinus radiata invading the native vegetation in central Chile? Demographic responses in a fragmented forest. Biol Invasions 7(2):243-249. https://doi.org/10.1007/ s10530-004-0740-5

Bustamante RO, Serey IA, Pickett STA (2003) Forest fragmentation, plant regeneration and invasion processes across edges in central Chile. In: Bradshaw GA, Marquet P (eds) How landscapes change. Springer, Berlin, pp 145-160. https://doi.org/10.1007/978-3-66205238-9 9
Butchart SHM, Walpole M, Collen B, van Strien A, Scharlemann JPW, Almond REA, Baillie JEM, Bomhard B, Brown C, Bruno J, Carpenter KE, Carr GM, Chanson J, Chenery AM, Csirke J, Davidson NC, Dentener F, Foster M, Galli A, Galloway JN, Genovesi P, Gregory RD, Hockings M, Kapos V, Lamarque JF, Leverington F, Loh J, McGeoch MA, McRae L, Minasyan A, Hernández Morcillo M, Oldfield TEE, Pauly D, Quader S, Reveng AC, Sauer JR, Skolnik B, Spear D, Stanwell-Smith D, Stuart SN, Symes A, Tierney M, Tyrrell TD, Vié JC, Watson R (2010) Global biodiversity: indicators of recent declines. Science 328(5982):11641168. https://doi.org/10.1126/science.1187512

Cardinale BJ, Gonzalez A, Allington GR, Loreau M (2018) Is local biodiversity declining or not? A summary of the debate over analysis of species richness time trends. Biol Conserv 219:175-183. https://doi. org/10.1016/j.biocon.2017.12.021

Carmona A, González ME, Nahuelhual L, Silva J (2012) Spatio-temporal effects of human drivers on fire danger in Mediterranean Chile. Bosque 33(3):321-328

Castillo M, Garfias R, Julio G, Gonzalez L (2012) Análisis de grandes incendios forestales en la vegetación nativa de Chile. Interciencia 37(11):796-804

Castillo ME, Molina JR, y Silva FR, García-Chevesich P, Garfias R (2017) A system to evaluate fire impacts from simulated fire behavior in Mediterranean areas of Central Chile. Sci Total Environ 579: 1410-1418. https://doi.org/10.1016/j.scitotenv.2016.11.139

Castillo SM, Plaza VÁ, Garfias SR (2020) A recent review of fire behavior and fire effects on native vegetation in Central Chile. Glob Ecol Conserv 24:01210. https://doi.org/10.1016/j.gecco.2020.e01210

Cifuentes-Croquevielle C, Stanton DE, Armesto JJ (2020) Soil invertebrate diversity loss and functional changes in temperate forest soils replaced by exotic pine plantations. Sci Rep 10:1-11. https://doi.org/ 10.1038/s41598-020-64453-y

Cincotta RP, Wisnewski J, Engelman R (2000) Human population in the biodiversity hotspots. Nature. 404(6781):990-992. https://doi.org/ $10.1038 / 35010105$

Clapp RA (1995a) The unnatural history of the Monterey pine. Geogr Rev 85(1):1-19. https://doi.org/10.2307/215551

Clapp RA (1995b) Creating competitive advantage: forest policy as industrial policy in Chile. Econ Geogr 71(3):273-296. https://doi.org/ $10.2307 / 144312$

Clapp RA (2001) Tree farming and forest conservation in Chile: do replacement forests leave any originals behind? Soc Nat Resour 14(4): 341-356. https://doi.org/10.1080/08941920119176

Cochrane MA, Schulze MD (1998) Forest fires in the Brazilian Amazon. Conserv Biol 12(5):948-950 http://www.jstor.com/stable/2387566

CONAF (2017) Análisis de la severidad de los incendios de magnitud temporada de incendios forestales 2016-2017. Corporación nacional forestal, Santiago de Chile, Chile

Contreras TE, Figueroa JA, Abarca L, Castro SA (2011) Fire regimen and spread of plants naturalized in central Chile. Rev Chil Hist Nat 84(3):303-323. https://doi.org/10.4067/S 0716 078X2011000300001

Crane M, Lindenmayer DB, Cunningham RB, Stein JA (2017) The effect of wildfire on scattered trees, 'keystone structures', in agricultural landscapes. Austral Ecol 42(2):145-153. https://doi.org/10.1111/ aec. 12414

Crutsinger GM, Collins MD, Fordyce JA, Gompert Z, Nice CC, Sanders NJ (2006) Plant genotypic diversity predicts community structure and governs an ecosystem process. Science 313(5789):966-968. https://doi.org/10.1126/science.1128326

Damschen EI, Haddad NM, Orrock JL, Tewksbury JJ, Levey DJ (2006) Corridors increase plant species richness at large scales. Science 313(5791):1284-1286. https://doi.org/10.1126/science.1130098 
Dawson TP (2001) Impact of forest fires on biodiversity in asean. ASEAN Biodivers 1(3):15-17

Donato DC, Fontaine JB, Campbell JL, Robinson WD, Kauffman JB, Law BE (2006) Post-wildfire logging hinders regeneration and increases fire risk. Science 311(5759):352-352. https://doi.org/10. 1126/science. 1122855

Driscoll DA, Lindenmayer DB, Bennett AF, Bode M, Bradstock RA, Cary GJ, Clarke MF, Dexter N, Fensham R, Friend G, Gill M, James S, Kay G, Keith DA, MacGregor C, Russell-Smith J, Salt D, Watson James JEM, Williams RJ, York A (2010) Fire management for biodiversity conservation: key research questions and our capacity to answer them. Biol Conserv 143(9):1928-1939. https:// doi.org/10.1016/j.biocon.2010.05.026

Echeverria C, Coomes D, Salas J, Rey-Benayas JM, Lara A, Newton A (2006) Rapid deforestation and fragmentation of Chilean temperate forests. Biol Conserv 130(4):481-494. https://doi.org/10.1016/j. biocon.2006.01.017

Echeverria C, Coomes DA, Hall M, Newton AC (2008) Spatially explicit models to analyze forest loss and fragmentation between 1976 and 2020 in southern Chile. Ecol Model 212(3-4):439-449. https://doi. org/10.1016/j.ecolmodel.2007.10.045

Fagan ME, DeFries RS, Sesnie SE, Arroyo-Mora JP, Chazdon RL (2016) Targeted reforestation could reverse declines in connectivity for understory birds in a tropical habitat corridor. Ecol Appl 26(5): 1456-1474. https://doi.org/10.1890/14-2188

Fahrig L (2003) Effects of habitat fragmentation on biodiversity. Annu Rev Ecol Evol Syst 34(1):487-515. https://doi.org/10.1146/ annurev.ecolsys.34.011802.132419

Fan C, Myint S (2014) A comparison of spatial autocorrelation indices and landscape metrics in measuring urban landscape fragmentation. Landsc Urban Plan 121:117-128. https://doi.org/10.1016/j. landurbplan.2013.10.002

Fardila D, Kelly LT, Moore JL, McCarthy MA (2017) A systematic review reveals changes in where and how we have studied habitat loss and fragmentation over 20 years. Biol Conserv 212:130-138. https://doi.org/10.1016/j.biocon.2017.04.031

Fuentes ER, Avilés R, Segura A (1989) Landscape change under indirect effects of human use: the Savanna of Central Chile. Landsc Ecol 2(2):73-80. https://doi.org/10.1007/BF00137151

Fuentes-Ramírez A, Salas-Eljatib C, González ME, Urrutia-Estrada J, Arroyo-Vargas P, Santibañez P (2020) Initial response of understorey vegetation and tree regeneration to a mixed-severity fire in old-growth Araucaria-Nothofagus forests. Appl Veg Sci 23(2): 210-222. https://doi.org/10.1111/avsc.12479

Garfias R, Castillo ME, Ruiz F, Julio GH, Quintanilla V, Antúnez J (2012) Caracterización socioeconómica de la población en áreas de riesgo de incendios forestales. Estudio de caso, interfaz urbanoforestal. Provincia de Valparaíso. Chile Central Territorium 19(2012):101-109. https://doi.org/10.14195/1647-7723 1912

Gaugris JY, Van Rooyen MW (2010) Evaluating the adequacy of reseves in the Tembe-Tshanini Complex: A case study in Maputaland, South Africa. Oryx 44(3):399-410. https://doi.org/10.1017/ S0030605310000438

Gómez-González S, Torres-Díaz C, Valencia G, Torres-Morales P, Cavieres LA, Pausas JG (2011) Anthropogenic fires increase alien and native annual species in the Chilean coastal matorral. Divers Distrib 17(1):58-67. https://doi.org/10.1111/j.1472-4642.2010. 00728.x

Gómez-González S, Paula S, Cavieres LA, Pausas JG (2017) Postfire responses of the woody flora of Central Chile: insights from a germination experiment. PLoS One 12(7):e0180661. https://doi.org/10. 1371/journal.pone. 0180661

Gómez-González S, Ojeda F, Fernandes PM (2018) Portugal and Chile: longing for sustainable forestry while rising from the ashes. Environ Sci Pol 81(2018):104-107. https://doi.org/10.1016/j.envsci.2017. 11.006
Gómez-González S, González ME, Paula S, Díaz-Hormazábal I, Lara A, Delgado-Baquerizo M (2019) Temperature and agriculture are largely associated with fire activity in Central Chile across different temporal periods. For Ecol Manag 433:535-543. https://doi.org/10. 1016/j.foreco.2018.11.041

Gonzalez ME, Veblen TT, Sibold JS (2005) Fire history of AraucariaNothofagus forests in Villarrica National Park, Chile. J Biogeogr 32(7):1187-1202. https://doi.org/10.1111/j.1365-2699.2005. 01262.x

Gonzalez ME, Veblen TT, Sibold JS (2010) Influence of fire severity on stand development of Araucaria araucana-Nothofagus pumilio stands in the Andean cordillera of south-central Chile. Austral Ecol 35(6):597-615. https://doi.org/10.1111/j.1442-9993.2009. 02064.x

Gonzalez ME, Lara A, Urrutia R, Bosnich J (2011) Cambio climático y su impacto potencial en la ocurrencia de incendios forestales en la zona

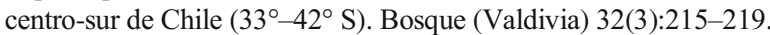
https://doi.org/10.4067/S0717-92002011000300002

González ME, Szejner P, Donoso PJ, Salas C (2016) Fire, logging and establishment patterns of second-growth forests in south-central Chile: implications for their management and restoration. Int J Agric Nat Resour 42(3):427-441. https://doi.org/10.4067/S071816202015000300011

Gonzalez C, Castillo M, García-Chevesich P, Barrios J (2018) DempsterShafer theory of evidence: a new approach to spatially model wildfire risk potential in central Chile. Sci Total Environ 613:10241030. https://doi.org/10.1016/j.scitotenv.2017.09.105

Gould W (2000) Remote sensing of vegetation, plant species richness, and regional biodiversity hotspots. Ecol Appl 10(6):1861-1870. https://doi.org/10.1890/1051-0761(2000)010[1861:RSOVPS]2.0. $\mathrm{CO} ; 2$

He T, Lamont BB, Pausas JG (2019) Fire as a key driver of Earth's biodiversity. Biol Rev 94:1983-2010. https://doi.org/10.1111/brv. 12544

Heinrichs S, Pauchard A (2015) Struggling to maintain native plant diversity in a peri-urban reserve surrounded by a highly anthropogenic matrix. Biodivers Conserv 24(11):2769-2788. https://doi.org/10. 1007/s10531-015-0964-y

Jorquera-Jaramillo C, Vega JA, Aburto J, Martinez-Tilleria K, Leon M, Perez M, Squeo FA (2012) Conservación de la biodiversidad en Chile: Nuevos desafíos y oportunidades en ecosistemas terrestres y marinos costeros. Rev Chil Hist Nat 85(3):267-280. https://doi.org/ 10.4067/S0716-078X2012000300002

Keeley JE, Pausas JG, Rundel PW, Bond WJ, Bradstock RA (2011) Fire as an evolutionary pressure shaping plant traits. Trends Plant Sci 16: 406-411. https://doi.org/10.1016/j.tplants.2011.04.002

Kerr JT, Ostrovsky M (2003) From space to species: ecological applications for remote sensing. Trends Ecol Evol 18(6):299-305. https:// doi.org/10.1016/S0169-5347(03)00071-5

Key CH, Benson NC (2006) Landscape assessment: sampling and analysis methods. Firemon: fire effects monitoring and inventory system. General Technical Report. USDA Forest Service, Rocky Mountain Research Station, Fort Collins. 1 CD.. 164. https://doi. org/10.2737/RMRS-GTR-164

Kottek M, Grieser J, Beck C, Rudolf B, Rubel F (2006) World map of the Köppen-Geiger climate classification updated. Meteorol Z 15(3): 259-263. https://doi.org/10.1127/0941-2948/2006/0130

Krauss J, Bommarco R, Guardiola M, Heikkinen RK, Helm A, Kuussaari M, Lindborg R, Öckinger E, Pärtel M, Pino J, Raatikainen KM, Sang A, Stefanescu C, Teder T, Zobel M, Steffan-Dewenter I, Pöyry J (2010) Habitat fragmentation causes immediate and timedelayed biodiversity loss at different trophic levels. Ecol Lett 13(5): 597-605. https://doi.org/10.1111/j.1461-0248.2010.01457.x

Kremer K, Bannister JR, Bauhus J (2020) Restoring native forests from Pinus radiata plantations: effects of different harvesting treatments on the performance of planted seedlings of temperate tree species in 
central Chile. For Ecol Manag 479(1):118585. https://doi.org/10. 1016/j.foreco.2020.118585

Langenfeld M (2017) Waldpolitik in Costa Rica und Chile-Ökosysteme im Spannungsfeld zwischen Markt und Nachhaltigkeit, Springer VS, Wiesbaden, 121-213. https://doi.org/10.1007/978-3-65814813-3

Lindenmayer DB, Franklin JF, Fischer J (2006) General management principles and a checklist of strategies to guide forest biodiversity conservation. Biol Conserv 131(3):433-445. https://doi.org/10. 1016/j.biocon.2006.02.019

Litton CM, Santelices R (2002) Early post-fire succession in a Nothofagus glauca forest in the Coastal Cordillera of south-central Chile. Int J Wildland Fire 11(2):115-125. https://doi.org/10.1071/ WF02039

Luebert P, Pliscoff F (2006) Sinopsis bioclimatica y vegetacional de Chile, Editorial Universitaria, Santiago de Chile, Chile, 40, 105117. https://doi.org/10.4067/S0718-34022008000200008

Luque CS (2017) Conservación de la biodiversidad en Chile: actores y territorio, la conectividad que falta. Revista Austral de Ciencias Sociales 7:111-128. https://doi.org/10.1016/j.ecolind.2015.03.042

Lustig A, Stouffer DB, Roigé M, Worner SP (2015) Towards more predictable and consistent landscape metrics across spatial scales. Ecol Indic 57:11-21

Magurran AE, McGill BJ (2011) Biological diversity—frontiers in measurement and assessment. Oxford University Press, Oxford

Martinez-Harms MJ, Caceres H, Biggs D, Possingham HP (2017) After Chile's fires, reforest private land. Science 356(6334):147-148. https://doi.org/10.1126/science.aan0701

McGarigal K, Cushman SA, Neel MC, Ene E (2002) FRAGSTATS: spatial pattern analysis program for categorical maps. United States Department of Agriculture, General Technical Report PNW-GTR-351. August 1995, 6. https://doi.org/10.2737/PNWGTR-351

McKee JK, Sciulli PW, Fooce CD, Waite TA (2004) Forecasting global biodiversity threats associated with human population growth. Biol Conserv 115(1):161-164

McWethy DB, Pauchard A, García RA, Holz A, González ME, Veblen TT et al (2018) Landscape drivers of recent fire activity (20012017) in south-central Chile. PLoS One 13(8):e0201195. https:// doi.org/10.1371/journal.pone.0205287

Miranda A, Altamirano A, Cayuela L, Lara A, Gonzalez M (2017) Native forest loss in the Chilean biodiversity hotspot: revealing the evidence. Reg Environ Chang 17:285-297. https://doi.org/10.1016/ S0006-3207(03)00099-5

Molina JR, Martin A, Drake F, Martin LM, Herrera MA (2015) Fragmentation of Araucaria araucana forests in Chile: quantification and correlation with structural variables. IForest. 9:244-252. https://doi.org/10.3832/ifor1399-008

Molina JR, Moreno N, Moreno R (2017) Influence of fire regime on forest structure and restoration of a native forest type in the southern Andean Range. Ecol Eng 102:390-396. https://doi.org/10.1016/j. ecoleng.2017.02.059

Montenegro G, Gómez M, Díaz F, Ginocchio R (2003) Regeneration potential of Chilean matorral after fire: an updated view. In 'Fire and climatic change in temperate ecosystems of the Western Americas.' (Eds TT Veblen, WL Baker, G Montenegro, TW Swetnam.) Vol. 160 pp. 375-403. (Springer New York: New York)

Montenegro G, Ginocchio R, Segura A, Keely JE, Gómez M (2004) Fire regimes and vegetation responses in two Mediterranean-climate regions. Rev Chil Hist Nat 77:455-464

Moreno T, Gibbons W (2007) The geology of Chile. Geological Society of London. https://doi.org/10.1144/GOCH

Myers N, Mittermeier RA, Mittermeier CG, da Fonseva GAB, Kent J (2000) Biodiversity hotspots for conservation priorities. Nature. 403:853-858. https://doi.org/10.1038/35002501
Nagendra H (2001) Using remote sensing to assess biodiversity. Int $\mathbf{J}$ Remote Sens 22(12):2377-2400. https://doi.org/10.1080/ 01431160117096

Naidoo R, Balmford A, Costanza R, Fisher B, Green RE, Lehner B, Malcolm TR, Ricketts TH (2008) Global mapping of ecosystem services and conservation priorities. Proc Natl Acad Sci 105(28): 9495-9500. https://doi.org/10.1073/pnas.0707823105

Ormazabal C (1993) The conservation of biodiversity in Chile. Rev Chil Hist Nat 66(4):383-402

Osepashvili I (2012) Conservation of biodiversity of Georgian forests: problems and perspectives. Legal Aspects of European Forest Sustainable Development, 213

Ovalle C, Aronson J, Del Pozo A, Avendano J (1990) The Espinal: agroforestry systems of the Mediterranean-type climate region of Chile. Agrofor Syst 10(3):213-239. https://doi.org/10.1007/ BF00122913

Pauchard A, Garcia RA, Pena E, Gonzalez C, Cavieres LA, Bustamante RO (2008) Positive feedbacks between plant invasions and fire regimes: Teline monspessulana (L.) K. Koch (Fabaceae) in central Chile. Biol Invasions 10(4):547-553. https://doi.org/10.1007/ s10530-007-9151-8

Peel MC, Finlayson BL, McMahon TA (2007) Updated world map of the Köppen-Geiger climate classification. Hydrol Earth Syst Sci 4(2): 439-473. https://doi.org/10.5194/hessd-4-439-2007

Pellissier V, Gallet S, Rozé F (2004) Comparison of the vegetation and seed bank on hedge banks of different ages in Brittany, France. Environ Manag 34(1):52-61. https://doi.org/10.1007/s00267-0040041-x

Peña E, Valenzuela L (2008) Incremento de los incendios forestales en bosques naturales y plantaciones forestales en Chile A. González (Ed.), Memorias del Segundo Simposio Internacional sobre Políticas, Planificación y Economía de los Programas de Protección Contra Incendios Forestales, Una visión global, USDA Forest Service GTR-PSW-208 (2008), pp. 595-612

Petit IJ, Campoy AN, Hevia MJ, Gaymer CF, Squeo FA (2018) Protected areas in Chile: are we managing them? Rev Chil Hist Nat 91(1):1-8. https://doi.org/10.1186/s40693-018-0071-z

Pimm SL, Jenkins CN, Abell R, Brooks TM, Gittleman JL, Joppa LN, Raven PH, Roberts CM, Sexton JO (2014) The biodiversity of species and their rates of extinction, distribution, and protection. Science 344(6187):1246752. https://doi.org/10.1126/science. 1246752

Pliscoff P, Fuentes-Castillo T (2011) Representativeness of terrestrial ecosystems in Chile's protected area system. Environ Conserv 38(3):303-311. https://doi.org/10.1017/S0376892911000208

Puerta-Piñero C, Espelta JM, Sánchez-Humanes B, Rodrigo A, Coll L, Brotons L (2012) History matters: previous land use changes determine post-fire vegetation recovery in forested Mediterranean landscapes. For Ecol Manag 279:121-127. https://doi.org/10.1016/j. foreco.2012.05.020

Ramírez C, Hauenstein E, Contreras D, San Martín J (1988) Degradación antrópica de la vegetación en la depresión intermedia de la Araucanía, Chile. Agro Sur (Chile) 16(1):1-14

Reidsma P, Tekelenburg T, Van den Berg M, Alkemade R (2006) Impacts of land-use change on biodiversity: an assessment of agricultural biodiversity in the European Union. Agric Ecosyst Environ 114(1):86-102. https://doi.org/10.1016/j.agee.2005.11.026

Rocchini D, Chiarucci A, Loiselle SA (2004) Testing the spectral variation hypothesis by using satellite multispectral images. Acta Oecol 26(2):117-120. https://doi.org/10.1016/j.actao.2004.03.008

Rojas I, Becerra P, Gálvez N, Laker J, Bonacic C, Hester A (2011) Relationship between fragmentation, degradation and native and exotic species richness in an Andean temperate forest of Chile Gayana. Botánica 68(2):163. https://doi.org/10.4067/S071766432011000200006 
Rojas IM, Pidgeon AM, Radeloff VC (2020) Restoring riparian forests according to existing regulations could greatly improve connectivity for forest fauna in Chile. Landsc Urban Plan 203:103895. https:// doi.org/10.1016/j.landurbplan.2020.103895

Rüger N, Gutiérrez AG, Kissling WD, Armesto JJ, Huth A (2007) Ecological impacts of different harvesting scenarios for temperate evergreen rain forest in southern Chile - a simulation experiment. For Ecol Manag 252(1-3):52-66. https://doi.org/10.1016/j.foreco. 2007.06.020

Sala OE, Chapin FS, Armesto JJ, Berlow E, Bloomfield J, Dirzo R, Huber-Sanwald E, Huenneke LF, Jackson RB, Kinzig A, Lodge DM, Mooney HA, Oesterheld M, Poff NL, Sykes MT, Walker BH, Walker M, Wall DH, Leemans R (2000) Global biodiversity scenarios for the year 2100. Science 287(5459):1770-1774. https:// doi.org/10.1126/science.287.5459.1770

Salas CF (1998) Fomento Forestal Decreto Ley 701 de 1974 y Ley 19.561. Artículo publicado por Temporada Agrícola, (11)

Salas C, Donoso PJ, Vargas R, Arriagada CA, Pedraza R, Soto DP (2016) The forest sector in Chile: an overview and current challenges. J For 114(5):562-571. https://doi.org/10.5849/jof.14-062

Smith-Ramírez C (2004) The Chilean coastal range: a vanishing center of biodiversity and endemism in South American temperate rainforests. Biodivers Conserv 13(2):373-393. https://doi.org/10. 1023/B:BIOC.0000006505.67560.9f

Smith-Ramírez C, Gonzalez ME, Echeverria C, Lara A (2015) Current state of ecological restoration in Chile: perspectives and challenges. Anales del Instituto de la Patagonia 43(1):11-21. https://doi.org/10. 4067/S0718-686X2015000100002

Solís R, Lobos G, Walker SF, Fisher M, Bosch J (2010) Presence of Batrachochytrium dendrobatidis in feral populations of Xenopus laevis in Chile. Biol Invasions 12(6):1641-1646. https://doi.org/ 10.1007/s10530-009-9577-2

Squeo FA, Estevez RA, Stoll A, Gaymer CF, Letelier L, Sierralta L (2012) Towards the creation of an integrated system of protected areas in Chile: achievements and challenges. Plant Ecol Divers 5(2): 233-243. https://doi.org/10.1080/17550874.2012.679012

Tachikawa T, Kaku M, Iwasaki A, Gesch DB, Oimoen MJ, et al. (2011) ASTER global digital elevation model version 2-summary of validation results. NASA

Toro J, Gessel SP (1999) Radiata pine plantations in Chile. In: Boyle, J.R., Winjum, J.K., Kavanagh, K., Jensen, E.C. 1999 Planted forests: contributions to the quest for sustainable societies. Springer, Dordrecht, 18(1). 33-44. https://doi.org/10.1023/A:1006597823190

Tuomisto H (2010a) A consistent terminology for quantifying species diversity? Yes, it does exist. Oecologia. 164(4):853-860. https:// doi.org/10.1007/s00442-010-1812-0

Tuomisto H (2010b) A diversity of beta diversities: straightening up a concept gone awry. Part 1 . Defining beta diversity as a function of alpha and gamma diversity. Ecography. 33(1):2-22. https://doi.org/ 10.1111/j.1600-0587.2009.05880.x

Tuomisto H (2010c) A diversity of beta diversities: straightening up a concept gone awry. Part 2. Quantifying beta diversity and related phenomena. Ecography 33(1):23-45. https://doi.org/10.1111/j. 1600-0587.2009.06148.x

Turner MG, Gardner RH (2015) Introduction to landscape ecology and scale. In: Landscape ecology in theory and practice. Springer, New York, pp 1-32. https://doi.org/10.1007/978-1-4939-2794-4

Turner W, Spector S, Gardiner N, Fladeland M, Sterling E, Steininger M (2003) Remote sensing for biodiversity science and conservation. Trends Ecol Evol 18(6):306-314. https://doi.org/10.1016/S01695347(03)00070-3

Úbeda X, Sarricolea P (2016) Wildfires in Chile: a review. Glob Planet Chang 146:152-161. https://doi.org/10.1016/j.gloplacha.2016.10. 004

Urrutia-Estrada J, Fuentes-Ramírez A, Hauenstein E (2018) Differences in floristic composition of Araucaria-Nothofagus forests affected by mixed levels of fire severity. Gayana Botánica 75(2):625-638. https://doi.org/10.4067/S0717-66432018000200625

Uuemaa E, Mander Ü, Marja R (2013) Trends in the use of landscape spatial metrics as landscape indicators: a review. Ecol Indic 28:100 106

Veloso A (2006) Batracios de las cuencas hidrográficas de Chile. In: Vila I, Veloso A, Schlatter R, Ramírez C (eds) Macrófitas y vertebrados de los sistemas límnicos de Chile. Editorial Universitaria, Santiago, pp 103-140

Weber M, Gonzalez S (2003) Latin American deer diversity and conservation: a review of status and distribution. Ecoscience 10(4):443454. https://doi.org/10.1080/11956860.2003.11682792

White DA, Balocchi-Contreras F, Silberstein RP, de Arellano PR (2020) The effect of wildfire on the structure and water balance of a high conservation value Hualo (Nothofagus glauca (Phil.) Krasser.) forest in central Chile. For Ecol Manag 472:118219. https://doi.org/10. 1016/j.foreco.2020.118219

Willis KJ, Birks HJB (2006) What is natural? The need for a long-term perspective in biodiversity conservation. Science 314(5803):12611265. https://doi.org/10.1126/science.1122667

Zhang K, Lin S, Ji Y, Yang C, Wang X, Yang C et al (2016) Plant diversity accurately predicts insect diversity in two tropical landscapes. Mol Ecol 25(17):4407-4419. https://doi.org/10.1111/mec. 13770

Zuloaga FO, Morrone O, Belgrano MJ (2008) Catalogue of the vascular plants of the southern cone (Argentina, southern Brazil, Chile, Paraguay and Uruguay). Missouri Botanical Garden Press

Publisher's note Springer Nature remains neutral with regard to jurisdictional claims in published maps and institutional affiliations. 